International Business Management 13 (4): 134-150, 2019

ISSN: $1993-5250$

(C) Medwell Journals, 2019

\title{
Stock Valuation, Strategic and Financial Analysis: A Case Study for Arab Potash Company (APOT) (Jordan)
}

\author{
${ }^{1}$ Walid Muhammad Masadeh, ${ }^{1}$ Wasfi Al Salamat, ${ }^{2}$ Rami Al Zebdieh and ${ }^{3}$ Anas Najeeb Ghazalat \\ ${ }^{1}$ Hashemite University, Zarqa, Jordan \\ ${ }^{2}$ Princess Sumaya University for Technology (PSUT), Amman, Jordan \\ ${ }^{3}$ Arab Open University Jordan, Amman, Jordan
}

\begin{abstract}
The aim and objective of this study is to make a stock valuation for Arab Potash Company (APC) based on two methods of strategic and financial performance analysis. Specially, we use is Strengths, Weaknesses, Opportunities and Threats (SWOT) analysis for strategic analysis and Discounted Free Cash Flow (DFCF), Dividend Discount Model (DDM) and ratios analysis for financial performance analysis. Based on the aforementioned analyses we came to a conclusion that the stock price of APO is overvalued as the SWOT analysis shows that APC is exposed to different kinds of risks such as, sales risk, financial risk, credit risk, liquidity risk, political risk. However, the volatility of sales is considered the most critical risk could affect the profitability of the APC. With regard to the financial analysis, the valuation of APC stock price arrives at the price of 7.272 JOD which is lower the market price of $16.90 \mathrm{JOD}$. The estimated value per share is driven by $35 \%$ of DFCF Model price of $5.92 \mathrm{JOD}$ and $65 \%$ of DDM price of $8.00 \mathrm{JOD}$. The $65 \%$ weight assigned to the DDM Model for two reasons: firstly, a flaw in the DFCF Model is that relies significantly on the terminal value. Secondly, the assumption that APC is a Blue-chip company that has reached maturity as it has been paying dividends consistently with rates that exceed its retention ratio in the last couple of years, thus, APC's stocks are considered to be "Income stocks". In addition, a positive relationship is found between the company's dividends and its closing price.
\end{abstract}

Key words: A stock valuation, equity valuation, $\mathrm{ROE}, \mathrm{ROA}$, companies, closing price

\section{INTRODUCTION}

This study aims to evaluate the stock price of Arab Potash Company (APC) and suggest whether the stock price of APO is over-or undervalues. Specifically, we are trying to answer the following question: is the current stock price indeed reflects the intrinsic value of APO. By doing, so, we are performing strategic and financial analysis. "Throughout the history there were times that the market made errors resulted in financial crisis, popular of which are "The great depression" in 1929-39, "the Black Monday" in 1987, "The internet bubble" in 1990's, the financial crises of 2008 , etc. Many studies and researches conducted in the attempt of seeking the explanation for those incidents from etc., suggested the theory of behavioral finance. The general idea of behavioral finance is that investors are not always rational and their actions depend on attitudes toward risk and beliefs about probabilities which causes a deviation in market prices from the intrinsic values. Although, the deviation only last for a short time and the market will eventually correct itself it gives incentive to investors to exploit these temporary efficiencies to make profit" (Le, 2017).

The first analysis, the strategic analysis is Strengths, Weaknesses, Opportunities and Threats (SWOT) analysis. Strategic management can be understood as the collection of decisions and actions taken by business management in consultation with all levels within the organization to determine the long-term activities of the organization (Houben et al., 1999). One of the main approaches used in analyzing the strategic management of an organization is the SWOT analysis which evaluates the opportunities, threats, strengths and weaknesses of an organization. By identifying its strengths, weaknesses, opportunities and threats, the organization can build strategies upon its strengths, eliminate its weaknesses and exploit its opportunities or use them to counter the threats. An internal environment appraisal identifies the strengths and weaknesses while the opportunities and threats are identified by an external environment appraisal

Corresponding Author: Walid Muhammad Masadeh, Hashemite University, Zarqa, Jordan 
Int. Business Manage., 13 (4): 134-150, 2019

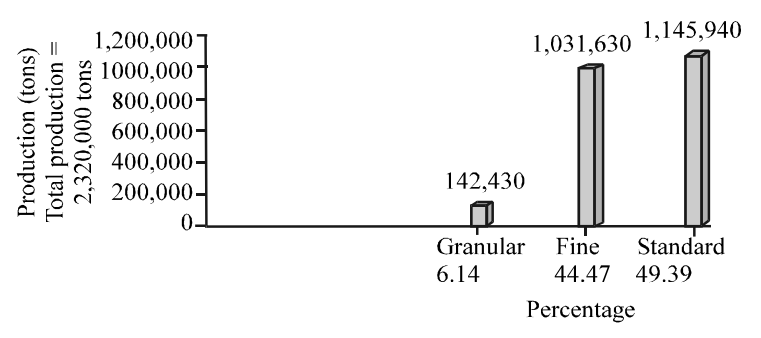

Fig. 1: Production by type 2017 (APC Annual Report)

(Dyson, 2004). SWOT analysis summarizes the most important internal and external factors that may affect the organization's future which is referred to as strategic factors (Kangas et al., 2003) (Fig. 1).

However, SWOT analysis does not provide an analytical means to determine the importance of the identified factors (i.e., strengths, weaknesses, opportunities and threats) or the ability to assess decision alternatives according to these factors. Yuksel and Dagdeviren (2007) suggest that even though SWOT analysis can successfully pinpoint the factors, individual factors are usually described briefly and very generally. For this reason, SWOT analysis possesses deficiencies in the measurement and evaluation steps. Therefore and in order to provide a comprehensive picture of the strategic and financial situation of APC this study will combine SWOT analysis with the analysis of APC financial performance.

Analysis of the financial performance of a company is an essential tool to obtain information about how the company operated in the previous period. Interpretation of the evolution of financial indicators does not always prove to be easy, requiring multiple calculations and combined approaches while the knowledge and understanding of a type of business reviewed are essential in the proper interpretation of the results. Therefore, the conclusions of the analysis carried out professionally will be able to describe the evolution of the company correctly and to support the user's investment and financing decisions. Ratio analysis has been a primary tool for conducting a financial analysis of any company. Different ratios highlight the overall financial position of a company.

In addition, to ratio analysis this study is using Discounted Free Cash Flow (DFCF) and Dividend Discount Model (DDM) to determine the fair value of APO stock price. DFCF is a valuation method used to estimate the fair value of a stock price by analyzing future free cash flow projections and discount them to arrive at a present value. If the value of DFCF analysis is higher than the current it would suggest that the stock price is overvalued and vice versa:

$$
\mathrm{DFCF}=\left(\mathrm{CF}_{1} /(1+\mathrm{i})\right)+\left(\mathrm{CF}_{2} /(1+\mathrm{i})^{2}\right)+, \ldots,\left(\mathrm{CF}_{\mathrm{n}} /(1+\mathrm{i})^{\mathrm{n}-1}\right)
$$

The fair value market estimate:

$$
\text { Value } \left.=\sum\left(\mathrm{CF}_{\mathrm{n}} /(1+\mathrm{i})^{\mathrm{n}}\right)+\mathrm{TV}_{\mathrm{t}} / 1+\mathrm{i}\right)^{\mathrm{t}}
$$

Where:

$\mathrm{CF}_{\mathrm{i}}=$ Cash flow in year $\mathrm{n}$

$\mathrm{i}=$ Discount rate

$\mathrm{TV}=$ The terminal year cash flow

$\mathrm{n}=$ The number of periods in the valuation model including the terminal year

DDM is another stock valuation method that is based on discounting predicted dividends to the present value. The premise behind DDM is that the fair value of a stock is determined by discounting all future dividends to its net present value:

$$
\text { Price per share }=D_{1} / r-g
$$

Where:

$D_{\mathrm{i}}=$ The estimated dividends for the next period

$\mathrm{r}=$ The cost of equity capital

$\mathrm{g}=$ The constant growth rate for dividends in perpetuity

The aforementioned valuation models can determine whether the stock price of APC is close to its intrinsic value or away from it. Dyson (2004) also, suggest that fair value models can assist in providing a sell/buy recommendation based on the valuation results. The premises of applying DDM and DFCF are:

- If estimated fair value bigger than the market price, investor should buy or hold the stock

- If estimated fair value is less than market price, investors shouldn't buy or sell the stock

\section{Literature review \\ Background}

Business description who is APC: APC is a public shareholding company established in 1956 in the Hashemite Kingdom of Jordan and specialized in manufacturing of potash with a paid-up capital of JD 83.318 million. APC is granted 100-year concession from the Jordanian government to extract, manufacture and market minerals from the Dead Sea until 2058 with the end of the concession period all the company's assets are transferred to the government. It is located in Amman, Aqaba and $\mathrm{Al}$ Ghor $\mathrm{Al}$ Safi. Currently, APC is the largest Jordanian industrial company with a global dimension and 


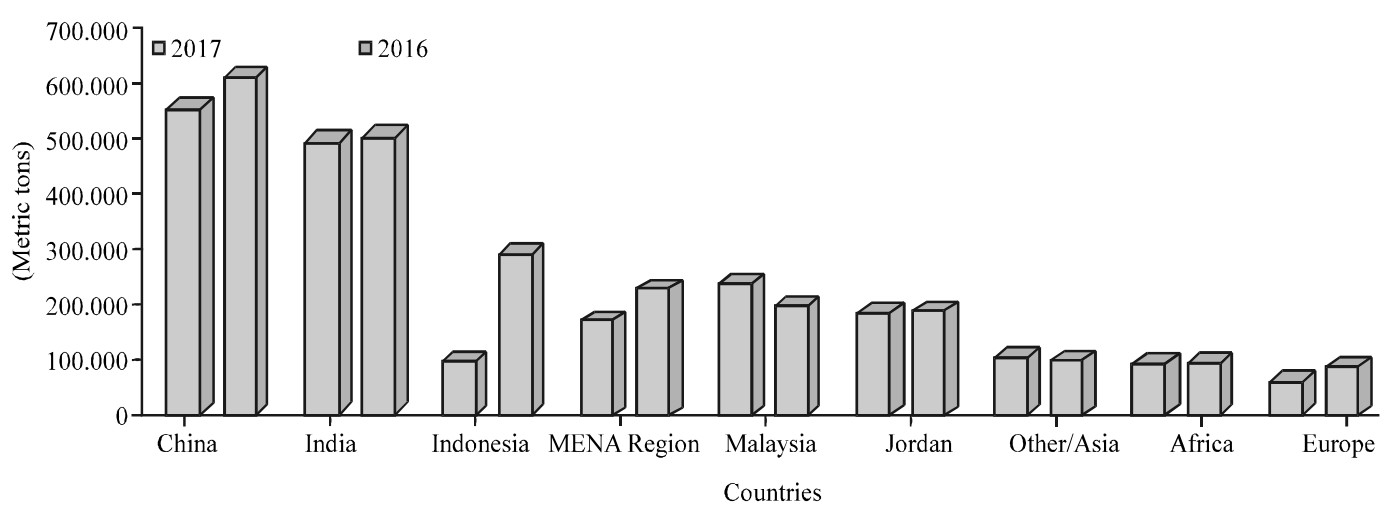

Fig. 2: APC sales distribution 2016 and 2017 (APC Annual Report)

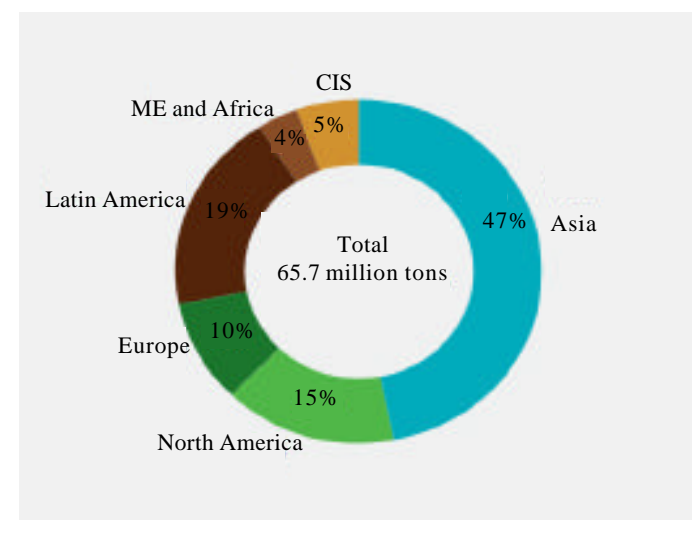

Fig. 3: Local and regional distribution 2017 (APC Annual Report)

the second largest company in the Amman stock exchange by the value. In 2016 APC was the largest potash producer worldwide by volume of production and the only producer of potash in the Arab world. The company manufactures and markets minerals from the dead sea. The company also invests in many manufacturing and supplementary industries related to salt and minerals of the dead sea including potassium nitrate, bromine and other derivatives. The potash reserves of Jordan are estimated " 40 metric tons". The Dead Sea reserves are divided equally between Jordan and occupied Palestine. Jordan is positioned the 9th globally in reserves. APC produces $2.35 \mathrm{mln}$.ton/year of potash due to it is the 4 plant planted in Jordan: the Hot Leach Plant (HLP), the Cold Crystallization Plant (CCP 1), the Industrial Potash Plant (IPP) and the new Cold Crystallization Plant (CCP 2), more than $90 \%$ of our products are exported to over 30 countries spanning Africa, Asia, Europe and the Middle East (Anonymous, 2016) (Fig. 2-4).

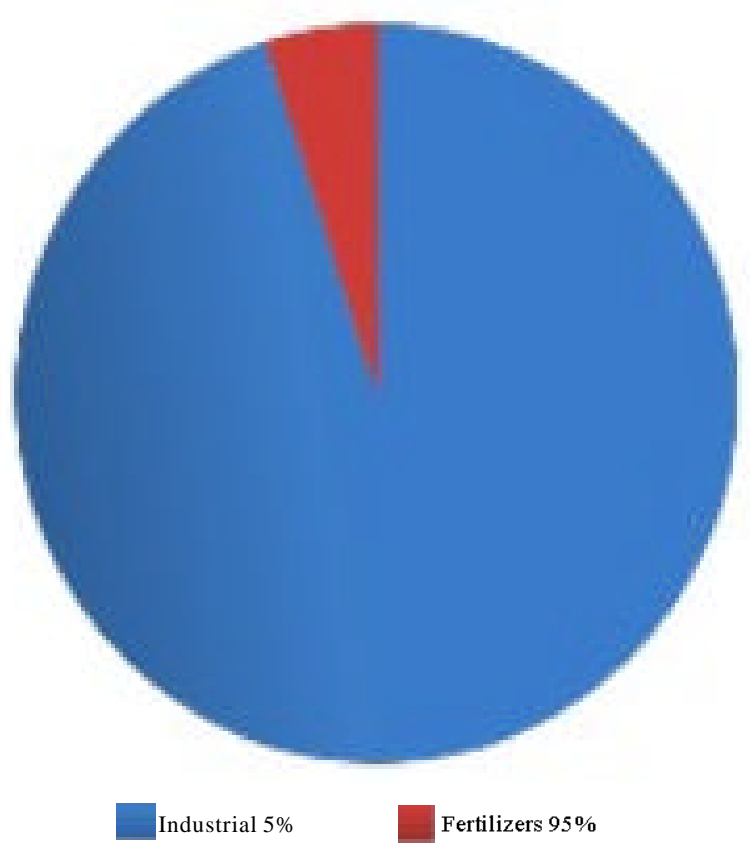

Fig. 4: Uses of potash worldwide (APC Annual Report)

Potash industry worldwide overview and the competitive position of APC: The environment is a significant focus for policymakers in the next few years and it is expected to be one of the significant factors influencing agriculture patterns and trends in the next decade (Fig. 5). This will impact the fertilizer industry in several ways. Cereals, oilseeds, fruits and vegetables account for about $78-80 \%$ of fertilizer use. The share of cereals is declining slowly as dietary patterns transform gradually and as fruits and vegetables claim higher prominence. Potash is primarily used for fertilizers (food for plants) in addition, to other industries that form a small percentage of potash production such as, soap, medicines, batteries, melting of drilling, food supplements, livestock and poultry. 
Int. Business Manage., 13 (4): 134-150, 2019

Table 1: APC's sales distribution in the top ten markets 2017 vs. 2016: (APC Annual Report)

\begin{tabular}{lclll}
\hline Rank & Quantity MT (2017) & Countries & Quantity MT (2016) & Countries \\
\hline 1 & 616,551 & China & 553,574 & China \\
2 & 511,759 & India & 498,089 & India \\
3 & 294,049 & Indonesia & 242,551 & Malaysia \\
4 & 206,004 & Malaysia & 188,565 & Jordan \\
5 & 194,477 & Jordan & 136,000 & Egypt \\
6 & 164,016 & Egypt & 104,808 & Indonesia \\
7 & 61,401 & S.Africa & 68,185 & S.Africa \\
8 & 39,479 & Mozambique & 41,065 & Pakistan \\
9 & 32,311 & Pakistan & 28,512 & Mozambique \\
10 & 46,472 & Saudi Arabia & 26,000 & Taiwan \\
& $2,166,519$ & Top ten total & $1,887,348$ & \\
& $92 \%$ & Top 10\% of sales & $93 \%$ & \\
& $2,360,244$ & Year sales total & $2,030,202$ & \\
\hline
\end{tabular}

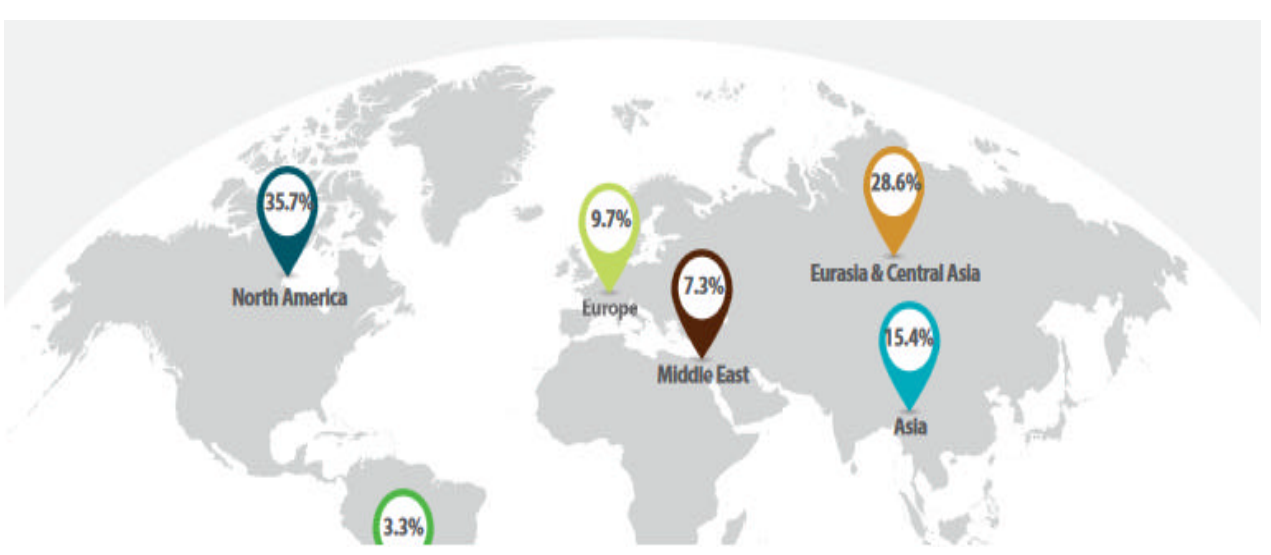

Fig. 5: Worldwide potash produces production capacity (APC Annual Report)

Agriculture is considered the main base for potash demand. The use and demand for agricultural products have been rising and this can be attributed to multiple factors including world population, global GDP growth, changes in world income and agricultural land. North America, Indonesia, Malaysia, Brazil, India and China are among the largest customers of potash fertilizers globally. The global demand for potash reach $42 \mathrm{mln}$.ton in 2017 , approximately $35.5 \mathrm{mln}$.ton goes to agriculture (Anonymous, 2016).

World potash production in 2017 hit a record. The increase of $2.8 \mathrm{mln}$.tons from the previous year was $4.5 \%$. Production in 2017 was also $2.5 \%$ more than the record year of 2015. The International Fertilizer Association (IFA) estimates the increase of the first half of 2017 over the same period in 2016 at over $16 \%$. The growth slowed down in the second half of the year as Canadian production was optimized to reduce costs drawing more tons from the newly commissioned rocanville expansions and slowing output from other high-cost mines. The new German-owned mine in Canada began production in the last quarter of 2017 and is estimated to have made about $300 \mathrm{k}$ tons. Production in Chile, Germany, the UK, Spain, Brazil and occupied Palestine fell back during 2017 while all other producers increased output. A new mine in Turkmenistan also began production in 2017 and is expected to ramp up in 2018 to about $1 \mathrm{mln}$.tons. The new eurochem mine in Russia is also likely to come on stream in 2018 while some higher cost facilities will start to fade out in Germany and the UK. The chilean producer has announced plans to reduce potash output in favor of other products in their portfolio (Anonymous, 2016) (Table 1). APC sales increased by $16 \%$ over the year (Anonymous, 2017). This increase is in line with the estimated growth in global deliveries. The growth in most regions was not structural but related to shipping times and logistics. APC share in Indonesia grew more than the average growth of the market but is still lower than volumes registered by APC some 15 years ago. Shipments to Europe increased significantly but are also short of historical levels for APC in Europe. APC volumes increased in China and India in line with contractual commitments and shipping schedules as well as long-term supply agreements. Sales rose in the local market and in Egypt. The growth of sales in the local and regional sector was about $13 \%$ and this growth is expected to continue as the emphasis is placed on these growing areas where geography provides an advantage. The top ten markets 


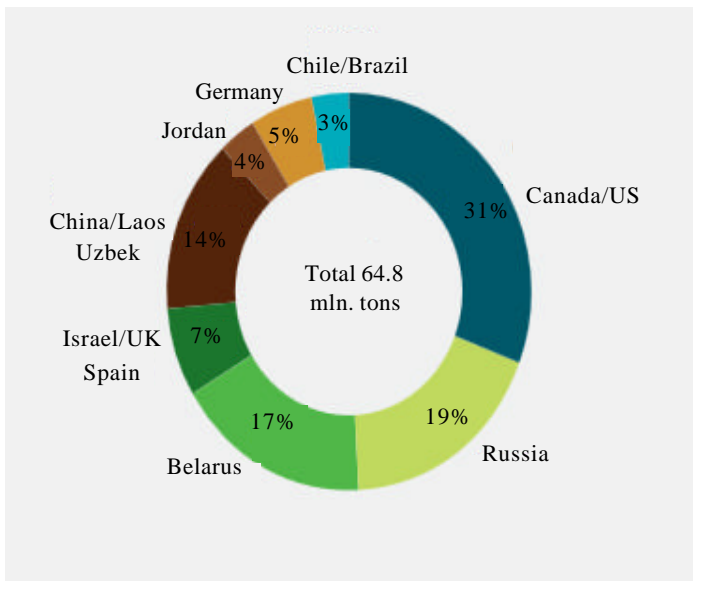

Fig. 6: Global potash production share in 2017(APC Annual Report)

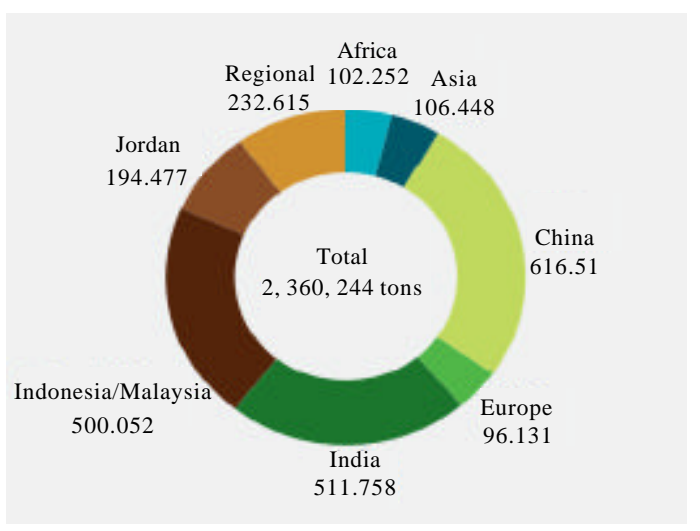

Fig. 7: APC's sales distribution in 2017 (MT) potash production share in 2017 APC Annual Report

for APC had a concentration of $91 \%$ of the total compared to $93 \%$ the year before (Anonymous, 2016) (Fig. 5-7). The top ten customers for APC were at $80 \%$ of the total sales compared to $79 \%$ the year before. Granular grade sales fell slightly in 2017 compared to the previous year. This was mainly due to technical issues with the compactors. However, a new unit was brought on stream at the end of 2017 and hence, sales in 2018 are expected to increase significantly. Europe and Africa represented about $67 \%$ of the total granular sales in 2017 compared to $45 \%$ the year before mainly due to the increase in granular sales to East Africa and reduction in sales to specific destinations in Asia. APC direct sales to non-fertilizer customers reached around $168 \mathrm{k} \mathrm{MT}$ compared to $165 \mathrm{k}$ MT the previous year. This represents $1.8 \%$ of APC total sales. Jordan Bromine, Halliburton, the major oil drilling services companies in the Middle East and the industrial customers in Asia accounted for most of these sales (APC, annual report).

\section{MATERIALS AND METHODS}

The aim and objective of this study is to do a stock valuation for APC by using two types of strategic and financial analysis. One of the main approaches used in analyzing the strategic management of an organization is the SWOT analysis which evaluates the opportunities, threats, strengths and weaknesses of an organization. By identifying its strengths, weaknesses, opportunities and threats the organization can build strategies upon its strengths, eliminate its weaknesses and exploit its opportunities or use them to counter the threats.

The main idea in utilizing the SWOT frame is to systematically appraise the SWOT factors and make them commensurable as regards their weightiness. Strategic management can be understood as the collection of decisions and actions taken by business management in consultation with all levels within the organization to determine the long-term activities of the organization (Houben et al., 1999). Analysis of the financial performance of a company is an essential tool to obtain information about how the company operated in the previous period. Interpretation of the evolution of financial indicators does not always prove to be easy, requiring multiple calculations and combined approaches while the knowledge and understanding of a type of business reviewed are essential in the proper interpretation of the results. The reference period for the study is 10 years beginning from the year 2013-2018. Data for the study has been taken from the annual reports of APC for the year 2013-2018.

\section{RESULTS AND DISCUSSION}

\section{Analysis, results and discussion of APC financial and strategic position}

Valuation analysis: The valuation of $\mathrm{APC}$ stock price arrives at the price of 7.272 , driven by $35 \%$ DFCF Model price at $5.92 \mathrm{JOD}$ and $60 \%$ of DDM price of $8.00 \mathrm{JOD}$. $65 \%$ weight assigned to the DDM Model for two reasons: firstly, a flaw in the DFCF Model is that relies significantly on the terminal value. Secondly, the assumption that APC is a Blue-chip company that has reached maturity as it has been paying dividends consistently with rates that exceed its retention ratio in the last couple of years. Thus, APC's stocks are considered to be "Income stocks" Le (2017).

Intrinsic valuation: $\mathrm{DFCF}$ was selected because $\mathrm{APC}$ has a positive free cash flow which is expected to increase over time. This method consists of a two-stage growth model. The first phase is based on a specific year-year forecast up to 2021 and the second phase is based on the constant growth of $3.33 \%$. Based on our DFCF the estimated price is 5.92 . 
Cost of equity: Cost of equity was calculated through the capital asset pricing model. The latest issue of treasury bills rate was used as the risk-free rate, estimated at $3.101 \%$. APC's beta was determined by using a 5 -year monthly stock price versus Amman stock exchange index which resulted in a beta of 1.425 and an adjusted ( used in calculating the cost of equity) of 1.285 . The expected market equity risk premium was defined to be $10.27 \%$ (Swath dam odorant estimate) which leads to a $16.30 \%$ cost of equity.

Weighted Average Cost of Capital (WACC): Weighted Average Cost of Capital (WACC) is determined to be $16.30 \%$. APC's capital structure is $99.99 \%$ equity; Therefore, its WACC is very similar to the cost of equity.

Terminal growth value: Terminal growth value is obtained a terminal growth rate of $3.33 \%$ by estimating the Real-GDP growth and inflation rate after 2022 (Going concern assumption) which was 1.327 and $2 \%$, respectively and adding them together (Table 2).

\section{Growth analysis}

Growth in sales: In estimating potash sales, the assumption is that there is a steady increase in potash demand globally. In 2017 three of the four quarterly earnings reports were available for earnings in the final quarter sales are estimated by weighting the transactions that occurred in the last quarter for the past 3 years to the total sales for these years then the results were averaged to estimate the sales in fourth quarter. As for the years 2018-2020, the growth in sales is based on the expected increase in Kemapco sales due to its latest agreement with Yara international, expected global GDP growth, changes in climate especially in agricultural countries and increase on crop demand. For the year 2021 and besides, the factors mentioned APC's new solar ponds expansion project which is set to be complete by 2021 is considered and many other factors (Table 3 ).

Basis of sales growth rate: Recently in 2018 Kemapco (a company affiliated with APC) (Anonymous, 2018) signed an agreement with Yare International a significant fertilizer producing company in India. This agreement will result in the construction of a new manufacturing plant which will increase the capacity by $175000 \mathrm{MT}$ to be $350000 \mathrm{MT}$; This project will require a total investment of $200 \mathrm{mln}$ dollar. Demand for agricultural product will increase for the following reason: over the 10-year outlook period, demand is projected to grow more slowly. Future growth in crop production will be attained mostly by increasing yields and growth in meat and dairy production.
Table 2: APC valuation analysis

\begin{tabular}{ll}
\hline Items & Values \\
\hline Risk free rate & $3.101 \%$ \\
$\beta$ & 1.425 \\
Adjusted $\beta$ & 1.28475 \\
Market risk premium & $10.27 \%$ \\
Camp (cost of equity) & $16.295383 \%$ \\
Cost of debt after tax & $7.73 \%$ \\
Market value equity (JOD) & $1,378,904,625$ \\
Market value debt (JOD) & 17 \\
Weight equity & $99.999999 \%$ \\
Weight debt & $0.000001 \%$ \\
WACC & $16.29538239 \%$ \\
\hline
\end{tabular}

Table 3: Growth analysis

\begin{tabular}{lccccc}
\hline Assumptions & $2017(\%)$ & $2018(\%)$ & $2019(\%)$ & $2020(\%)$ & $2021(\%)$ \\
\hline Sales growth rate & 14.85 & 09.70 & 07.00 & 05.50 & 13.00 \\
Cost of goods & 12.40 & 07.00 & 05.00 & 03.00 & 10.00 \\
sold growth rate & & & & & \\
Assets growth rate & -1.93 & 02.00 & -2.00 & -2.00 & 07.00 \\
Finance revenue rate & 03.82 & 03.82 & 03.82 & 03.82 & 03.82 \\
$\begin{array}{l}\text { Depreciation rate } \\
\text { Tax rate }\end{array}$ & 28.00 & 28.00 & 28.00 & 28.00 & 28.00 \\
\hline
\end{tabular}

Agricultural trade is expected to grow more slowly but remain less sensitive to weak economic conditions than other sectors. Real prices are expected to remain flat or decline for most commodities. Climate change: for the decade a warming of $0.1^{\circ}$ is expected globally an increase in temperature is better for plant growth, thus, an increase in fertilizer demand is most likely to occur.

Growth in cost of sales: The estimate of the growth in the cost of sales is dependent on APC's effective cost controlling mission. For example, in 2016 APC managed to maintain a steady price per unit despite the medawar factory shutting down for 2 months and it's contracts being delayed and in 2017 the increase in the cost of sales was lower than the increase in sales. Besides APC was recently granted a right to use a gas pipeline as a fuel replacement instead of liquid fuel which is expected to drive down energy costs even further (Anonymous, 2013; Anonymous, 2013, 2014).

Assets growth rate: Assets growth rate is based on many factors including. Maintenance costs which are reflected in the CAPEX. Depreciation expense charges which reduce the book value of assets and APC's upcoming expansion projects such as the expansion of solar ponds in 2021 and Kempaco's agreement with Yara international which is expected to boost its production capacity significantly.

\section{Financial analysis}

Sales: After reviewing the financial statement of APC, the results show that APC's (Anonymous, 2015) sales had been reasonably stable between 2012 and 2015 even 
though potash prices had been declining globally. However, it suffered a significant decrease in 2016 due to the unusual delays in completing contracts with India and China and because of the medawar mine closure due to maintenance which had an estimated production opportunity cost of $120,000 \mathrm{MT}$.

Profitability analysis: For APC the most profitability ratios decreased dramatically in 2016 because of the decrease in sales that was due to the reasons explained above. Besides, the company's finance revenue has been falling steadily, since, 2012 due to the decline in cash. The decrease in stock can be attributed to 1 . Distribution of large amounts cash dividend from its retained earnings, 2 . Increase in the number of investments in 2016 related to buildings and equipment, investments in high amount in joint ventures and expansions projects in progress. Besides, APC purchased bonds for about 21,199,000 JOD.

Return on Equity (ROE): Decreased in 2016 because the company experienced a drop in net income due to a decrease in sales and because the company incurred expenses with the shutting down of $\mathrm{Al}$ Medawar factory which meant the company had to withstand fixed costs during that period which include depreciation expenses, salaries expenses and utility expenses. Equity decreased about $32,658,000$ JOD because the company paid about this amount from its retained earnings as dividends this indicates that the company is mature and has some stuffiness in assets in the short run.

Return on Assets (ROA): Decreased in 2016 due to the decrease in net income. Total assets declined in 2016 especially the current assets their decline can be attributed to the fact that the company paid dividends from its retained earnings and settled some amount of their trade payables for about 9,000,000 JOD of their other current liabilities they also made significant investments in long-term assets which will be discussed in our asset management section. Different profitability ratios decreased dramatically in 2016 for the same reasons that affected sales and expenses.

Short term asset management: When we analyze short-term asset management we are concerned mainly with what happens to working capital (current assets and current liabilities) from our research we found the ratios were relatively stable from 2012-2015 but it diverted in 2016 for the following reasons: working capital decreased in high amounts in 2016 due to a decrease in current assets mainly cash and receivables which were used to pay dividends from retained earnings, investing in bonds and settlement of a significant amount of their trade payable.
Current liabilities: Decreased in 2016 but an amount less than the decrease in current assets its decline was due to the decrease in potash mining fees from 23,698,000 to $4,063,000$. Income tax payable decreased because APC's earnings before tax decreased. Working capital turnover decreased in 2016 due to the decrease in sales in a higher amount than the reduction in working capital receivables were relatively stable because receivables and sales decrease comparatively in the same percentage inventory and payable turn over increased in 2016 because inventory and payable had a higher percentage drop in percent higher than the reduction in cost of sales, so, the company incurred some manufacturing cost such as salaries and wages and depreciation on manufactory and utilities regardless the level of outputs.

Long-term assets management: Long-term assets and net long-term assets increased during the years especially in 2016, due to the increases in projects, investments joined ventures and the main reason for this dramatic increase is the investment in bonds market (government bond) with coupon rate $6.125 \%$ paid semiannually about of 21199 thousand JOD. PP\&E has been decreasing annually due to high depreciation expenses which were higher than the investment in PP\&E the last couple of years. Net long-term assets turn over and net long-term holdings to sales were reasonably stable except for 2016 where sales decreased, long-term assets also reduced along with the long-term liabilities for the reasons explained above.

Liquidity: APC is highly liquid as it measures very well in terms of liquidity ratios, the company can cover its current liabilities from current assets or only from cash many times and these ratios increase dramatically in 2016 despite the decrease in current assets and cash due to the significant reduction of current liabilities which outpaced the decline in current assets.

Debt and long-term solvency: APC's capital structure is a mixture of debt and equity with equity weighting approximately 99.9\%. APC's capital has decreased in high amounts during 2016 because of the decrease in the book value of equity. Ratios related to debt such as the debt to capital and debt to equity ratios are immaterial $(<0.1 \%)$ and this indicates that the company doesn't rely on financial leverage.

\section{Risks analysis}

Sales risk: These factors include price fluctuations in universal markets and a slowing of the global economy, causing a reduction in demand for potash. Because potash is mainly used as a fertilizer any changes that may 
affect this sector such as a decrease in agriculture production, production prices, weather-related factors such as $\mathrm{d}$ rought and floods or other factors that may lead farmers to plant $1 \mathrm{e}$ ss and as a result $\mathrm{d}$ ecline their use of fertilizers. APC could reduce the effect of such risks by finding new markets and usages while adapting to market changes and customer demand.

Political risk: The alliance with the United States of America and the United Kingdom and the good relations with its neighbors (such as Saudi Arabia) as well as its good relationship with Xch other Arab neighbors, bring political stability to the Hashemite Kingdom of Jordan. Also, the situation in Syria could affect the investment environment in Jordan positively.

Economic risk: The region, in general is experiencing unrest because of economic, political and social circumstances which may affect commercial and investment activities in the area. This includes potential labor strikes and disputes at the company's facilities and the public service sector. At present, APC's employee-benefit packages are among the highest in the region. Also, management keeps open channels of communication with labor unions and worker representatives. Every 2 years APC and the union sign a labor agreement that covers all needs and concerns of the workers and the union to ensure smooth and uninterrupted operations.

Legal risk: The tax rate in Jordan could be changed over the years because of the need of government to cover the deficit in the budget which in turn will affect the number of profits for Arab Potash company. However, there is no tax on capital gains and dividends. On the other hand, Arab Potash company exports a high percentage of its product to Foreign countries, so, the changes in regulations in those countries will affect the profits of Arab Potash company. The policies of importing countrie's government, specifical subsidies for the agricultural sector, may influence the number of crops and consequently the sales of fertilizer products.

Environmental risk: The amount of extraction is affected by the decreasing the level of water of the Dead Sea year after year. Besides, the factories of the Arab Potash company are located in Ghor Al Safi where this area is exposed to earthquakes and floods. To avoid this problem, all promises in that area are built in individual specifications and with full insurance.

Operational risks: The process of extracting and producing Potash requires enormous quantities of water and energy. Therefore, resource scarcity or high prices of water and energy may affect the number and amount of production. The Potash company started using power generators on diesel material. The company continues to explore cheaper energy alternatives. Furthermore, it starts using less expensive and environmentally friendly natural gas of heavy fuel. The company is considering installing a working turbine on natural gas and diesel for electricity and steam. The Potash company also finances the construction of wadi hammad dam that will contribute to bridging the water needs of local communities and some needs of the Potash company.

The company mainly depends on Aqaba port for loading and shipment Potash. The Potash company in partnership with a mining Jordan phosphate company, establishes a new port to facilitate and improve shipping operations through a joint venture company: Jordanian industrial company. Note that, there is a significant increase in volume shipments in bulk as well as bulk cargo in bulk ships. Also, there is a possibility of using roads shipping to neighboring countries which will increase the distribution flexibility.

Financial risks: The current ratio for APC is 8.3 times in 2016 which means that the APC can cover its short-term debts. Also, it has low bankruptcy costs where its Debt/Equity ratio is equal to $0 \%$ in 2016 (Fig. 8).

Interest rate risk: The $\mathrm{APC}$ is exposed to interest rate risk on its interest-bearing assets and liabilities (bank deposits and term loans).

Credit risk: The APC uses letters of credit and credit insurance to ensure that sales are made to customers with appropriate credit history and do not exceed acceptable credit exposure limits.

Liquidity risk: The APC's policy is to maintain sufficient cash and cash equivalents or have available funding through an adequate amount of committed credit facilities to meet its commitments.

Currency risk: The APC's transactions in US Dollar do not give rise to foreign currency risk because the Jordanian Dinar is fixed against the US Dollar (USD 1.41 for each one JD).

Competition risk: Using porter's five forces model to understand the competitiveness of APC business environment and determine APC's weaknesses and strengths in terms of competitiveness. 
Int. Business Manage., 13 (4): 134-150, 2019

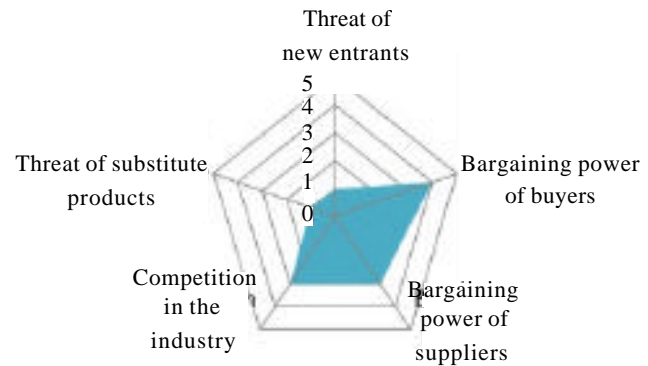

Fig. 8: Porter's five forces model

The threat of new entrants: Substantial barriers to entry because Canada, Russia and Belarus together account for more than $80 \%$ of global reserves also production and supply of Potash is concentrated with six of the largest potash producers accounting for over $60 \%$ of global capacity. Only companies with high characteristic (high capacity, low production cost) can face global competition. Significant economies of scale to profit (Small players will not be successful)

\section{Competition in the industry:}

. Large companies dominate the industry (high concentration, low balance)

- Potash industry operates in a global market (international factor)

- Lower of existing competitors (merger potash corp and agrium to competition for increasing market share)

- Natural resources are differently located (potash reserve is high in some countries)

\section{Bargaining power of suppliers:}

Exist of raw material (available for the producer)

Potash significance is increasing with time

\section{Bargaining power of buyers}

- Lacks a diversified or balance market (concentration threat)

- Low switching cost (product is undifferentiated)

- Long-term contracts are involved

- The risk of buyer's backward integration is insignificant

\section{The threat of substitute products:}

No superior substitute exists

The intervention of the human factor: genetically modified crops can reduce demand for potash

\section{SWOT analysis \\ Strengths:}

The sole producer of potash in the Arab world
- The potash company is granted a 100-year concession from the Jordanian government to extract The new agreement with Yare international Low cost of export when exporting to India, China and the far East compared to others potash produced compared to other potash producing companies

\section{Weaknesses:}

Low capacity of potash production compared to other potash producing companies

Its only source of salt extraction is the Dead Sea which has a small size compared to the producing countries of the potash

Threats:

. The weakness of the Jordanian economy

. The current political situation in the Middle East

Fluctuations in global prices of potash

Reduce China's export volumes as it seeks self-consumption

\section{Opportunities:}

Increase global market share

Obtain new investments to boost the company's profits

Signing new agreements that will enhance the company's sales (Appendix 1-13)

\section{CONCLUSION}

Good performances within a company are the results of correct interaction of the business management with its internal and or external environment. To operate successfully in this respect, the company must concentrate its future objectives on its strengths while averting tendencies related to the companie's weaknesses.

The study found in terms of financial and strategic analysis that APC's sales had been reasonably stable between (2012-2015) even though potash prices had been declining globally; however, it suffered a significant decrease in 2016 due to unusual delays in completing contracts with India and China and because of the medawar mine closure due to the maintenance that had an estimated production opportunity cost of $120 \mathrm{kMT}$. The APC is exposed to different kinds of risks such as sales risk, operational risk, economic risk, financial risk, credit risk, interest rate risk, liquidity risk, political risk, legal risk and environmental risk. However, the volatility of sales is considered the most critical risk could affect the profitability of the APC. 
Moreover, the results reveal that APC performed well regarding return available to all the investors measured as return on average capital employed. It also shows that APC offered a higher return to equity shareholders measured regarding return on equity and earnings per share during the reference period. However, declining return on average net worth on year basis is a cause of concern for APC. Besides, this it was also found that debt policy of the company is very conservative as it uses a lower degree of risk to avoid financial risk and insolvency risk. Though APC is performing well at least regarding book value measures as highlighted above, markets do not seem to be favoring the stock of APC as it is offering a lower premium on its share in terms of low $\mathrm{P} / \mathrm{E}$ ratio which also offers an opportunity to conduct further research.

\section{RECOMMENDATIONS}

The future plans of the APC are increasing the market share of a company in global markets, raising the company's ability to support the Jordanian national economy and generate jobs and keep focusing on reducing costs to the lowest achievable level. The company is working on several projects to reduce costs now and in the future. The production volume in 2016 is equal to $2.32 \mathrm{mln}$.tons. Therefore, APC's production is ranked as the 8 th worldwide with $3 \%$ of the world production. From the analysis a stock valuation of APC by using two types of strategic and financial analysis. We issue a sell recommendation with a target price of 7.272 JOD/ share. The valuation of APC stock price arrives at this price driven by $35 \%$ of DFCF Model price at $5.92 \mathrm{JOD}$ and $60 \%$ of DDM price of 8.00 JOD. The $65 \%$ weight assigned to the DDM Model for two reasons: firstly, a flaw in the DFCF Model is that relies significantly on the terminal value. Secondly, the assumption that APC is a Blue-chip company that has reached maturity as it has been paying dividends consistently with rates that exceed its retention ratio in the last couple of years; thus, APC's stocks are considered to be "Income stocks". Besides, a positive relationship is found between the company's dividends and its closing price. We came to a conclusion that the stock price of APO is overvalued as the valuation of APC stock price arrives at the price of 7.272 JOD which is lower the market price of $16.90 \mathrm{JOD}$.

\section{ACKNOWLEDGEMENT}

We would like to thank the journal editors, anonymous referees for their insightful comments. Any errors are our own.

\section{APPENDIX}

Appendix 1: Balance sheet (Thousand JOD)

\begin{tabular}{|c|c|c|c|c|c|c|c|c|c|c|c|c|c|c|c|c|c|c|}
\hline \multirow{3}{*}{$\begin{array}{l}\text { Assets } \\
\text { Moncurrent assets } \\
\text { property, plant and equipment } \\
232.078\end{array}$} & \multicolumn{2}{|c|}{2013} & \multicolumn{2}{|r|}{2014} & \multicolumn{2}{|r|}{2015} & \multicolumn{2}{|r|}{2016} & \multicolumn{2}{|c|}{$2017 \mathrm{~F}$} & \multicolumn{2}{|r|}{$2018 \mathrm{~F}$} & \multicolumn{2}{|r|}{$2019 \mathrm{~F}$} & \multicolumn{2}{|c|}{$2020 \mathrm{~F}$} & \multicolumn{2}{|c|}{$2021 \mathrm{~F}$} \\
\hline & & 100 & 333,947 & 77100 & 291,846 & 5100 & 241,57 & $573 \quad 100$ & 1002 & 227,599 & 100 & 232,151 & sod & 227,508 & & 222,958 & 900 & 238,565 \\
\hline & & & & & & & & & 100 & 14,301 & 100 & 13,279 & JoD & 12,258 & 300 & 11,236 & 100 & 10,215 \\
\hline Intangbie Assets & & 100 & & .100 & & SOD & & .100 & 100 & 74,620 & 100 & 76,112 & NoD & 74,590 & 100 & 73,098 & 100 & 78,215 \\
\hline -project in progreess & & 100 & 26,928 & 28100 & 39,683 & 3100 & 68,9 & 932100 & 100 & 146,396 & 100 & 153,242 & 100 & 160,408 & & 167,910 & $\mathrm{SOD}$ & 175,762 \\
\hline 76,088 investment in asocites and joint ventures & & 100 & 87,02 & 023 YOD & 104,74 & 16100 & 133,6 & 608100 & 100 & 660 & 100 & 660 & sod & 660 & 500 & 660 & 100 & 650 \\
\hline 139,856 & & & & & & & & & 100 & 21,103 & 100 & 21,007 & 100 & 20,911 & sod & 20,815 & 100 & 20,719 \\
\hline Fruncial assets at far value through other comprehenenive & & 100 & 920 & 100 & 715 & 100 & & 71100 & 100 & 5,287 & 100 & 4,774 & 100 & 4,440 & 100 & 4,196 & 100 & 3,650 \\
\hline & & & & & & & & & 100 & 18,723 & 100 & 18,626 & 100 & 18,529 & sod & 18,433 & 100 & 18,338 \\
\hline Total nonkurrent assets & SOD & 471,468 & 1004 & 459,614 & 100 & 466,902 & 100 & 494,910 & 1000 & 494,387 & 100 & 506,572 & 200 & 507,045 & 100 & 508,069 & 100 & 535,908 \\
\hline \multicolumn{19}{|l|}{ Current assots } \\
\hline Employees housing lours & 900 & 2,299 & 9100 & 2,321 & 100 & 2,960 & 100 & 2,896 & 100 & 2833 & 100 & 2,772 & SOD & 2,712 & 100 & 2,654 & 100 & 2,596 \\
\hline Accounts receviable & 500 & 52,480 & 0100 & 61,546 & 100 & 68,453 & 100 & 52,349 & 100 & 60,123 & 100 & 65,955 & 200 & 70,572 & 100 & 74,453 & 100 & 84,132 \\
\hline Inventories & 300 & 53,126 & 6100 & 17,924 & 100 & 31,462 & 100 & 20,922 & 100 & 10,111 & 100 & 10,819 & 100 & 11,360 & sod & 11,700 & 100 & 12,871 \\
\hline Spare parts and supplies & 300 & 54,040 & 0100 & 52,313 & 100 & 42,533 & 100 & 40,511 & 100 & 39,729 & 100 & 40,524 & SOD & 39,713 & soD & 38,919 & 100 & 41,643 \\
\hline Other current assets & 100 & 67,565 & 100 & 59,946 & 100 & 65,349 & 100 & 53,926 & 100 & 61,934 & 100 & 67,942 & 200 & 72,698 & JoD & 76,696 & 100 & 86,666 \\
\hline Cashon hand and bank balance & 100 & 304,437 & $7 \quad 100$ & 294,759 & 100 & 3398,463 & 100 & 255,140 & 100 & 231,280 & 100 & 210,964 & 100 & 224,865 & 100 & 758,995 & 100 & 287.015 \\
\hline Total current assets & 500 & 533,947 & 7100 & 488,809 & 100 & 549,220 & 100 & 425,744 & 100 & 406,010 & 100 & 398,975 & 500 & 421,919 & 100 & 463,417 & 100 & 514,923 \\
\hline TOTAL ASSETS & 200 & $1,005,415$ & 5100 & 948,423 & 100 & $1,016,122$ & 100 & 920,654 & 1000 & 900,397 & 100 & 905,547 & 500 & 928,965 & Jo0 s & 971,486 & 1001 & $1,050.831$ \\
\hline \multicolumn{19}{|l|}{ Equity and Liabilites } \\
\hline \multicolumn{19}{|l|}{ Equity } \\
\hline Paid in capital & sod & 83,318 & 8100 & 83,318 & 100 & 83,318 & 100 & 83,318 & 100 & 83,318 & 100 & 83,318 & NoD & 83,318 & 100 & 83,318 & 100 & 83,318 \\
\hline Statutory reserve & 100 & 50,454 & 4100 & 50,454 & 100 & 50,464 & 100 & 50,464 & 100 & 50,454 & 100 & 50,464 & SOD & 50,464 & 300 & 50,464 & 100 & 50,454 \\
\hline voluntary reserve & 300 & 80,699 & $9 \mathrm{JOD}$ & 80,699 & 100 & 80,699 & 100 & 80,699 & 100 & 30,699 & 100 & 80,699 & sod & 80,699 & 200 & 80,699 & 100 & 80,699 \\
\hline Fär value reserve & yod & 263 & 3100 & 58 & 100 & 114 & 100 & 3 & 100 & 3 & 100 & 3 & 100 & 3 & 200 & 3 & 100 & 3 \\
\hline Retahed exrings & .00 & 672,744 & $4 \quad 100$ & 645,443 & 100 & 677595 & 100 & 645,048 & 1000 & 621,705 & 100 & 627,181 & $\mathrm{OOD}$ & 649,789 & 100 & 600,708 & 100 & 763.862 \\
\hline Total Equity & 500 & 886,488 & 8100 & 860,982 & 100 & 892,190 & 100 & 859,532 & 1008 & 836,189 & 100 & 841,665 & 100 & 864,273 & $100 \mathrm{~s}$ & 905,192 & TOD & 978.346 \\
\hline \multicolumn{19}{|l|}{ Non- current liabilities } \\
\hline Long term loans & $\mathrm{JOD}$ & 119 & $9 \mathrm{JoD}$ & 85 & 100 & 51 & Jo0 & 17 & 100 & & 100 & & 100 & & JOD & & 100 & \\
\hline other man-current liabilities & 100 & 14,147 & $7 \mathrm{y} 00$ & 9,106 & 100 & 9,326 & 100 & 9,918 & 100 & 10,548 & 100 & 11,217 & 200 & 11,979 & 200 & 12,586 & 100 & 13,492 \\
\hline Total non-current Isbilitis & 100 & 14,256 & $5 \mathrm{J00}$ & 9,191 & 100 & 9,377 & 100 & 9,935 & 100 & 10,548 & 100 & 11,217 & DOD & 11,929 & JOD & 12,685 & 100 & 13,492 \\
\hline \multicolumn{19}{|l|}{ Current liabilities } \\
\hline current portion of long term lasen & 100 & 1,228 & 8100 & 34 & 100 & 34 & 100 & 34 & 100 & 17 & 100 & & 100 & . & 100 & & 100 & \\
\hline Potach mining fees due to the gowrnment of the $\mathrm{H}$ & 100 & 5,949 & 900 & 6,330 & 100 & 23,698 & 100 & 4,063 & 100 & 4,666 & 100 & 5,119 & 300 & 5,477 & 100 & 5,779 & 100 & 6,530 \\
\hline Trade pyables and other accruak & $\mathrm{JOD}$ & 31,239 & $9 \mathrm{JOD}$ & 28,941 & 100 & 25,535 & JoD & 17468 & 100 & 19,634 & 100 & 21,008 & NOD & 22,059 & SOD & 22,721 & 100 & 24,993 \\
\hline Income tax provisic & 300 & 10,187 & 7100 & 5,097 & 100 & 29,039 & 100 & 4,187 & 100 & 11,496 & 100 & 14,014 & SOD & 16,440 & 300 & 18,943 & 100 & 23,145 \\
\hline Other current liabilities & JoD & 56,058 & 8500 & 37,848 & 100 & 36,249 & JoD & 25,435 & 100 & 17847 & 100 & 12,523 & yod & 8,787 & 100 & 6,166 & 100 & 4,325 \\
\hline Total current liabilitios & 100 & 104,651 & 1100 & 78.250 & 100 & 114,555 & 100 & 51,187 & 100 & 53,651 & 100 & 52,664 & NoD & 52,763 & SoD & 53.608 & 100 & 58.993 \\
\hline Total Labilities & 500 & 118,927 & 7100 & 87,441 & 100 & 173,932 & 100 & 61,122 & 100 & 64,208 & 100 & 63,882 & TOD & 64,692 & TOD & 66,294 & 100 & 72,485 \\
\hline TOTAL EQUITY AMD LABBILTIES & JoD & $1,005,415$ & 5100 & 948,423 & 100 & $1,016,122$ & 100 & 920,654 & $100 \mathrm{~s}$ & 900,397 & 100 & 905,547 & 100 & 928,965 & $100 \mathrm{~s}$ & 971A86 & 1001 & $1,050,831$ \\
\hline
\end{tabular}


Int. Business Manage., 13 (4): 134-150, 2019

Appendix 2: Common size of balance sheet

\begin{tabular}{|c|c|c|c|c|c|c|c|c|c|}
\hline Common size of balance sheet & 2013 & 2014 & 2015 & 2016 & $2017 \mathrm{~F}$ & $2018 \mathrm{~F}$ & $2019 \mathrm{~F}$ & $2020 \mathrm{~F}$ & $2021 \mathrm{~F}$ \\
\hline \multicolumn{10}{|l|}{ Assets } \\
\hline \multicolumn{10}{|l|}{ Non-current assets } \\
\hline property, plant and equipment & $33.215 \%$ & $30.772 \%$ & $23.774 \%$ & $25.20 \mathrm{~B} \%$ & $25.278 \%$ & $25.637 \%$ & $24.490 \%$ & $22.950 \mathrm{r}$ & $22.702 \%$ \\
\hline Intangible Aasets & & $0.000 \%$ & $0.000 \%$ & $0.000 \%$ & $1.588 \%$ & $1.466 \%$ & $1.319 \%$ & $1.157 \%$ & $0.972 \%$ \\
\hline $0.000 \%$ project in progress & & $2.678 \%$ & $4.184 \%$ & $6.784 \%$ & $8.287 \mathrm{x}$ & $8.405 \%$ & $8.029 \%$ & $7.524 \%$ & $7.443 \%$ \\
\hline 8.265\% investment in associates and joint ventures & & $8.655 \%$ & $11.044 \%$ & $13.149 \%$ & $16.259 \%$ & $16.923 \%$ & $17.267 \%$ & $17.284 \%$ & $16.726 \%$ \\
\hline 15.191\% Financial assets at fair value through other comprehensive income & & $0.092 \%$ & $0.075 \%$ & $0.076 \%$ & $0.073 \%$ & $0.073 \%$ & $0.071 \%$ & $0.065 \%$ & $0.063 \%$ \\
\hline $0.072 \%$ Finance assets at amortized cost & & $0.000 \%$ & $0.000 \%$ & $0.000 \%$ & $2.344 \%$ & $2.320 \% 6$ & $2.251 \%$ & $2.143 \%$ & $1.972 \%$ \\
\hline 2.303\% Deferred tax assets & & $0.373 \%$ & $0.323 \%$ & $0.305 \%$ & $0.587 \%$ & $0.527 \%$ & $0.478 \%$ & $0.432 \%$ & $0.347 \%$ \\
\hline $0.674 \%$ Employee housing loans & & $1.880 \%$ & $2.062 \%$ & $1.862 \%$ & $2079 \%$ & $2057 \%$ & $1.995 \%$ & $1.897 \%$ & $1.745 \%$ \\
\hline Total non-current assets & $46.893 \%$ & $48.461 \%$ & $45.949 \%$ & $53.756 \%$ & $54.908 \%$ & $55.941 \%$ & $54.582 \%$ & $52.298 \%$ & $50.998 \%$ \\
\hline \multicolumn{10}{|l|}{ Current assets } \\
\hline Employees housing loans & $0.229 \%$ & $0.245 \%$ & $0.291 \%$ & $0.315 \%$ & $0.315 \%$ & $0.306 \%$ & $0.292 \%$ & $0.273 \%$ & $0.247 \%$ \\
\hline Accounts receivable & $5.220 \%$ & $6.489 \%$ & $6.737 \%$ & $5.686 \%$ & $6.677 \mathrm{~m}$ & $7.283 \%$ & $7.597 \%$ & $7.665 \%$ & $8.006 \%$ \\
\hline Inventories & $5.284 \%$ & $1.890 \%$ & $3.096 \%$ & $2.273 \%$ & $1.123 \%$ & $1.195 \%$ & $1.223 \%$ & $1.204 \mathrm{r}$ & $1.225 \%$ \\
\hline Spare parts and supplies & $5.375 \%$ & $5.516 \%$ & $4.186 \%$ & $4.400 \%$ & $4.412 \%$ & $4.475 \%$ & $4.275 \%$ & $4.006 \%$ & $3.963 \%$ \\
\hline Other current assets & $6.720 \%$ & $6.321 \%$ & $6.431 \%$ & $5.857 \%$ & $6.879 \%$ & $7503 \%$ & $7.826 \%$ & $7.895 \%$ & $8.247 \%$ \\
\hline Cash on hand and bank balance & $30.280 \%$ & $31.079 \%$ & $33.309 \%$ & $27.713 \%$ & $25.686 \%$ & $23.297 \%$ & $24.206 \%$ & $26.660 \%$ & $27.313 \%$ \\
\hline Total current assets & $53.10 \% \mathrm{~m}$ & $51.539 \%$ & $54.051 \%$ & $46.244 \%$ & $45.092 \%$ & $44.05 \%$ & $45.418 \%$ & $47.702 \%$ & $49.002 \%$ \\
\hline TOTAL ASSETS & $100.000 \%$ & $100.000 \%$ & $100.000 \%$ & $100.000 \%$ & $100.000 \%$ & $100.000 \%$ & $100,000 \%$ & $100.000 \%$ & $100.000 \%$ \\
\hline \multicolumn{10}{|l|}{ Equity and tiabilities } \\
\hline \multicolumn{10}{|l|}{ Equity } \\
\hline Paid in capital & $8.287 \%$ & $8.785 \%$ & $8.200 \%$ & $9.050 \%$ & $9.253 \%$ & $9.201 \%$ & $8.969 \%$ & $8.576 \%$ & $7.929 \%$ \\
\hline Statutory reserve & $5.019 \%$ & $5.321 \%$ & $4.966 \%$ & $5.481 \%$ & $5.605 \%$ & $5.573 \%$ & $5.432 \%$ & $5.195 \%$ & $4.802 \%$ \\
\hline Voluntary reserve & $8.026 \%$ & $8.509 \%$ & $7.942 \%$ & $8.765 \%$ & $8.963 \%$ & $8.912 \%$ & $8.687 \%$ & $8.30 \%$ & $7.680 \%$ \\
\hline Fair value reserve & $0.026 \%$ & $0.006 \%$ & $0.011 \%$ & $0.000 \%$ & $0.000 \%$ & $0.000 \%$ & $0.000 \%$ & $0.000 \%$ & $0.000 \%$ \\
\hline Retained earnings & $66.813 \%$ & $68.160 \%$ & $66.684 \%$ & $70.064 \%$ & $69.048 \%$ & $69.260 \%$ & $69.948 \%$ & $71.098 \%$ & $72.691 \%$ \\
\hline Total Equity & $88.171 \%$ & $90.780 \%$ & $87.803 \%$ & $93.361 \%$ & $92869 \%$ & $92.946 \%$ & $93.036 \%$ & $93.176 \%$ & $93.102 \%$ \\
\hline \multicolumn{10}{|l|}{ Non-current liabilities } \\
\hline Long-term loans & $0.012 \%$ & $0.009 \%$ & $0.005 \%$ & $0.002 \%$ & $0.000 \%$ & $0.000 \%$ & $0.000 \%$ & $0.000 \%$ & $0.000 \%$ \\
\hline Other non-current liabilitios & $1.407 \%$ & $0.960 \%$ & $0.918 \%$ & $1.077 \%$ & $1.171 \%$ & $1.239 \%$ & $1.284 \%$ & $1.306 \%$ & $1.284 \%$ \\
\hline Total non current liabilities & $1.419 \%$ & $0.969 \%$ & $0.923 \%$ & $1.079 \%$ & $1.171 \%$ & $1.239 \%$ & $1.284 \%$ & $1.306 \%$ & 1.28 .96 \\
\hline \multicolumn{10}{|l|}{ Cuine lutaitum } \\
\hline ournes porties of long ters loan & $0.125 \%$ & 0.0004 & $0.001 \mathrm{~K}$ & $0.00 \%$ & 0.002 & $\cos 0 \%$ & $0.000 \mathrm{~N}$ & 0.000 & $0 \cos$ \\
\hline Potanh nining foon due to the government of the Hathento kingtom of Iendas & asass & 0.6675 & $2.20 \mathrm{sh}$ & 0.441\% & estan & asss & 0.5005 & $0 . \operatorname{ses} s$ & o.5n: \\
\hline Irabe peyabies ond ceter actiuath & $2.20 \%$ & $1 \mathrm{msh}$ & 25125 & $1.90 \mathrm{rk}$ & $2.1 \mathrm{ars}$ & 2000 & $2 \mathrm{mss}$ & $2.1 \mathrm{~m}$ & $2 \operatorname{man}$ \\
\hline hoone tax provisen & $1013 \%$ & $0.53 \times$ & 28545 & $0.455 \%$ & $12 m$ & ISeEs & $17 N$ N & $1996 \mathrm{k}$ & $2.202 \%$ \\
\hline Other annet lablibis & $15 \mathrm{sm}$ & $2301 \mathrm{x}$ & $1507 \mathrm{~s}$ & $2.001 \times$ & 19125 & $\operatorname{Lan}$ & $0.5 e a k$ & oasis & 0.4121 \\
\hline 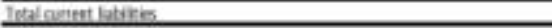 & 104906 & B2512 & 112205 & SSAOS & 5.958 & $5816 \mathrm{~s}$ & 5,650 & $5 \sinh$ & SELAY \\
\hline Tetal tiabities & 11.039 & $0.220 \mathrm{~K}$ & $12.197 \mathrm{~m}$ & C.6905 & 2.1315 & 70545 & sests & 0.925 & $6 \operatorname{sen}$ \\
\hline TDIAL EQUTY ASO LUAUITES & $1000000 \mathrm{~s}$ & 1000000 & $100.000 \mathrm{k}$ & $100000 \mathrm{~N}$ & 10000006 & 1050000 & $100000 \times 1$ & 1000000 & 300.0000 \\
\hline
\end{tabular}

Appendix 3: Income statement

\begin{tabular}{|c|c|c|c|c|c|c|c|c|c|c|c|c|c|c|c|c|c|c|}
\hline \multicolumn{19}{|l|}{ Income Statement (Thousand J00) } \\
\hline & & 2013 & & 2014 & & 2015 & & 2016 & & $2017 \mathrm{~F}$ & & $2018 \mathrm{~F}$ & & $2019 \mathrm{~F}$ & & $2020 \mathrm{~F}$ & & $2021 \mathrm{~F}$ \\
\hline Sales & 100 & 521,209 & 100 & 535,465 & 100 & 527,527 & 100 & 369,651 & 100 & 424,544 & 100 & 465,725 & 100 & 498,326 & 100 & 525,734 & $x 00$ & 594,079 \\
\hline Cost of sales & 100 & 277,418 & 100 & 335,298 & 100 & 252,890 & 100 & 239,853 & 100 & 269,595 & 100 & 288.466 & 100 & 302,890 & 100 & 311976 & 100 & 343,174 \\
\hline Gross profit & 100 & 243,791 & JoD & 200,167 & 100 & 274,637 & 100 & 179,798 & 100 & 154,949 & 100 & 177,259 & 100 & 195,435 & 100 & 213,757 & 100 & 250,905 \\
\hline Adminituathe expenses & 100 & 16,175 & 100 & 21,611 & 100 & 22,301 & 100 & 16,843 & 100 & 17,399 & 100 & 17,653 & 100 & 18,091 & 100 & 18,539 & 100 & 19,005 \\
\hline seling and distributian expenses & 100 & 14,858 & 100 & 15,796 & 100 & 18,006 & 100 & 15,679 & 100 & 18,007 & 100 & 19,754 & 100 & 21,137 & 100 & 22,299 & 100 & 25,198 \\
\hline Ployalty to the Government of Jordan & 100 & 25,949 & JoD & 13,330 & 100 & 23,698 & 100 & 4,063 & 100 & 4,666 & 100 & 5,119 & 100 & 5,477 & 100 & 5,779 & XOD & 6,530 \\
\hline Depreciation experses & 100 & 63,813 & 100 & 62,749 & 100 & 63,527 & 100 & 64,706 & 100 & 63,457 & 100 & 64,726 & 100 & 63,432 & 100 & 62,163 & 100 & 66,515 \\
\hline Amortization evenses & 100 & & 100 & & 100 & & $J O D$ & & 100 & 1,021 & 100 & 1,021 & 100 & 1,021 & 100 & 1,021 & 100 & 1,021 \\
\hline Operating profit & 100 & 122,986 & 100 & 85,681 & 100 & 147,105 & 100 & 28,507 & 100 & 50,398 & 100 & 68,985 & 100 & 86,278 & 100 & 103,955 & 100 & 132,636 \\
\hline Finance revenue & 100 & 15,822 & 100 & 10,948 & 100 & 10,452 & 100 & 8,413 & 100 & 8,845 & 100 & 8,068 & 100 & 8,599 & 100 & 9,905 & 100 & 10,976 \\
\hline Donations expenses & 100 & 10,074 & JOD & 7,633 & 100 & 10,138 & $J O D$ & 8,118 & 100 & 9,324 & 100 & 10,228 & 100 & 10,944 & 100 & 11.546 & 100 & 13,047 \\
\hline France costs and tank charges & 100 & 1,027 & 100 & 641 & 100 & 1,525 & 100 & 1,366 & 100 & 1,569 & 100 & 1,721 & 100 & 1,842 & 100 & 1,943 & $x D 0$ & 2,195 \\
\hline Other income, net & 100 & 1,588 & IOD & 3,338 & 100 & 879 & 100 & 15,771 & 100 & 18,113 & 100 & 19,870 & 100 & 21,261 & 100 & 22,430 & 100 & 25,345 \\
\hline Other expenses & 100 & 1,501 & JOD & 344 & 100 & . & 100 & , & 100 & , & 100 & , & 100 & , & 100 & , & 100 & , \\
\hline Foxeign currency exchange differences & 100 & 851 & 100 & 2.270 & 100 & 2,100 & 100 & 255 & 100 & 255 & 100 & 255 & 100 & 255 & 100 & 255 & $X 0 D$ & 255 \\
\hline Profit before tax and gain from associates and joint ventures & 100 & 128,645 & JOD & 89,079 & 100 & 144,673 & 100 & 42,952 & 100 & 66,209 & 100 & 84,719 & 100 & 103,098 & 100 & 122547 & jod & 153,461 \\
\hline Company's share of profit of associates and joint wentures & 100 & 19,511 & JOD & 21,228 & 100 & 18,471 & 100 & 28,606 & 100 & 32,854 & 100 & 36,041 & 100 & 38,564 & 100 & 40,685 & 100 & 45,974 \\
\hline Revaluation of kbamic Development Bank laan for Jordan Magnesia Company & 100 & 283 & 100 & 102 & 100 & 320 & 100 & & 100 & & 100 & & 100 & & 100 & & $y 00$ & . \\
\hline Profit before tax & 100 & 147,873 & 100 & 110,205 & 100 & 162,824 & 100 & 71,558 & 100 & 99,062 & 100 & 220,759 & 100 & 141,661 & 100 & 163,231 & 500 & 199,435 \\
\hline Income tar experse & 100 & 17,212 & JOD & 10,529 & 100 & 31,691 & 100 & 4,124 & 100 & 11,496 & 100 & 14,014 & 100 & 16,440 & 100 & 18,943 & 100 & 23,145 \\
\hline Profit for the year & 100 & 130,661 & 100 & 99,676 & 100 & 131,133 & 100 & 67,434 & 100 & 87,566 & 100 & 106,745 & 100 & 125,272 & 100 & 144,288 & 100 & 176,290 \\
\hline
\end{tabular}


Appendix 4: Common size of income statement

\begin{tabular}{|c|c|c|c|c|c|c|c|c|c|}
\hline \multicolumn{10}{|l|}{ Common Slze of Income Statement } \\
\hline & 2013 & 2014 & 2015 & 2016 & $2017 \mathrm{~F}$ & $2018 \mathrm{~F}$ & $2019 \mathrm{~F}$ & $2020 \mathrm{~F}$ & $2021 \mathrm{~F}$ \\
\hline Sales & $100.00 \%$ & $100.00 \%$ & $100.00 \%$ & $100.00 \%$ & $100.00 \%$ & $100.00 \%$ & $100.00 \%$ & $100.00 \%$ & $100.00 \%$ \\
\hline Cost of sales & $53.23 \%$ & $62.62 \%$ & $47.94 \%$ & $64.89 \%$ & $63.50 \%$ & $61.94 \%$ & $60.78 \%$ & $59.34 \%$ & $57.77 \%$ \\
\hline Gross profit & $46.77 \%$ & $37.38 \%$ & $52.06 \%$ & $35.11 \%$ & $36.50 \%$ & $38.06 \%$ & $39.22 \%$ & $40.66 \%$ & $42.23 \%$ \\
\hline Administrative expenses & $3.10 \%$ & $4.04 \%$ & $4.23 \%$ & $4.56 \%$ & $4.10 \%$ & $3.79 \%$ & $3.63 \%$ & $3.53 \%$ & $3.20 \%$ \\
\hline selling and distribution expenses & $2.85 \%$ & $3.14 \%$ & $3.41 \%$ & $4.24 \%$ & $4.24 \%$ & $4.24 \%$ & $4.24 \%$ & $4.24 \%$ & $4.24 \%$ \\
\hline Royalty to the Government of Jordan & $4.98 \%$ & $2.49 \%$ & $4.49 \%$ & $1.10 \%$ & $1.10 \%$ & $1.10 \%$ & $1.10 \%$ & $1.10 \%$ & $1.10 \%$ \\
\hline Depreciation expenses & $12.24 \%$ & $11.72 \%$ & $12.04 \%$ & $17.50 \%$ & $14.95 \%$ & $13.90 \%$ & $12.73 \%$ & $11.82 \%$ & $11.20 \%$ \\
\hline Amortization expenses & $0.00 \%$ & $0.00 \%$ & $0.00 \%$ & $0.00 \%$ & $0.24 \%$ & $0.22 \%$ & $0.20 \%$ & $0.19 \%$ & $0.17 \%$ \\
\hline Operating profit & $23.60 \%$ & $16.00 \%$ & $27.89 \%$ & $7.71 \%$ & $11.87 \%$ & $14.81 \%$ & $17.31 \%$ & $19.77 \%$ & $22.33 \%$ \\
\hline Finance revenue & $3.04 \%$ & $2.04 \%$ & $1.98 \%$ & $2.28 \%$ & $2.08 \%$ & $1.73 \%$ & $1.73 \%$ & $1.88 \%$ & $1.85 \%$ \\
\hline Donations expenses & $1.93 \%$ & $1.43 \%$ & $1.92 \%$ & $2.20 \%$ & $2.20 \%$ & $2.20 \%$ & $2.20 \%$ & $2.20 \%$ & $2.20 \%$ \\
\hline Finance costs and bank charges & $0.20 \%$ & $0.12 \%$ & $0.29 \%$ & $0.37 \%$ & $0.37 \%$ & $0.37 \%$ & $0.37 \%$ & $0.37 \%$ & $0.37 \%$ \\
\hline Other income, net & $0.30 \%$ & $0.62 \%$ & $0.17 \%$ & $4.27 \%$ & $4.27 \%$ & $4.27 \%$ & $4.27 \%$ & $4.27 \%$ & $4.27 \%$ \\
\hline Other expenses & $0.29 \%$ & $0.06 \%$ & $0.00 \%$ & $0.00 \%$ & $0.00 \%$ & $0.00 \%$ & $0.00 \%$ & $0.00 \%$ & $0.00 \%$ \\
\hline Foreign currency exchange differences & $0.16 \%$ & $0.42 \%$ & $0.40 \%$ & $0.07 \%$ & $0.06 \%$ & $0.05 \%$ & $0.05 \%$ & $0.05 \%$ & $0.04 \%$ \\
\hline Profit before tax and gain from assoclates and joint ventures & $24.68 \%$ & $16.64 \%$ & $27.42 \%$ & $11.62 \%$ & $15.60 \%$ & $18.19 \%$ & $20.69 \%$ & $23.31 \%$ & $25.83 \%$ \\
\hline Company's share of profit of associates and joint ventures & $3.74 \%$ & $3.96 \%$ & $3.50 \%$ & $7.74 \%$ & $7.74 \%$ & $7.74 \%$ & $7.74 \%$ & $7.74 \%$ & $7.74 \%$ \\
\hline Revaluation of Islamic Development Bank loan for Jordan Magnesla Company & $0.05 \%$ & $0.02 \%$ & $0.06 \%$ & $0.00 \%$ & $0.00 \%$ & $0.00 \%$ & $0.00 \%$ & $0.00 \%$ & $0.00 \%$ \\
\hline Profit before tax & $28.37 \%$ & $20.58 \%$ & $30.87 \%$ & $19.36 \%$ & $23.33 \%$ & $25.93 \%$ & $28,43 \%$ & $31.05 \%$ & $33.57 \%$ \\
\hline Income tax expense & $3.30 \%$ & $1.97 \%$ & $6.01 \%$ & $1.12 \%$ & $2.71 \%$ & $3.01 \%$ & $3.30 \%$ & $3.60 \%$ & $3.90 \%$ \\
\hline Profit for the year & $25.07 \%$ & $18.61 \%$ & $24.86 \%$ & $18.24 \%$ & $20.63 \%$ & $22.92 \%$ & $25.13 \%$ & $27.45 \%$ & $29.67 \%$ \\
\hline
\end{tabular}

Appendix 5: Financial ratios

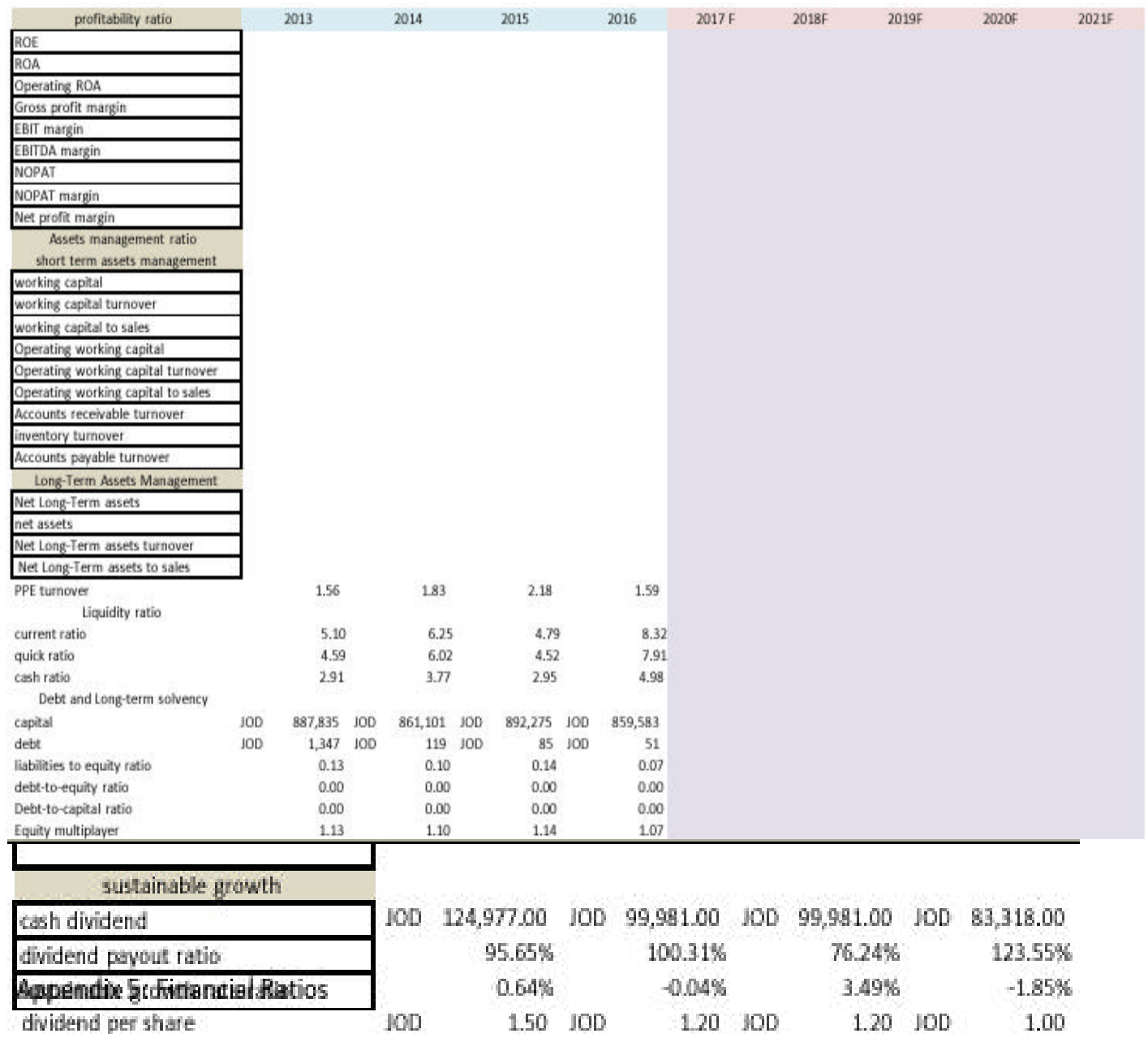


Appendix 6: Assumption

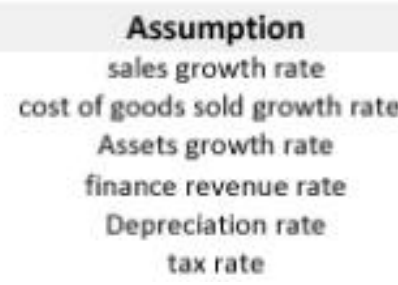

\begin{tabular}{|rrrrr|}
\hline 2017 & \multicolumn{1}{c}{2018} & \multicolumn{1}{c}{2019} & \multicolumn{1}{c}{2020} & 2021 \\
\hline $14.85 \%$ & $9.70 \%$ & $7.00 \%$ & $5.50 \%$ & $13.00 \%$ \\
$12.40 \%$ & $7.00 \%$ & $5.00 \%$ & $3.00 \%$ & $10.00 \%$ \\
$-1.93 \%$ & $2.00 \%$ & $-2.00 \%$ & $-2.00 \%$ & $7.00 \%$ \\
$3.82 \%$ & $3.82 \%$ & $3.82 \%$ & $3.82 \%$ & $3.82 \%$ \\
$28 \%$ & $28 \%$ & $28 \%$ & $28 \%$ & $28 \%$ \\
$12 \%$ & $12 \%$ & $12 \%$ & $12 \%$ & $12 \%$ \\
\hline
\end{tabular}

Appendix 7: Free cash flow and CAPEX

\begin{tabular}{|c|c|c|c|c|c|c|c|c|c|c|c|c|}
\hline capital expenditures & & \multicolumn{2}{|l|}{2016} & \multicolumn{2}{|c|}{2017} & \multicolumn{2}{|l|}{2018} & \multicolumn{2}{|l|}{2019} & \multicolumn{2}{|l|}{2020} & \multirow{2}{*}{$\begin{array}{r}2021 \\
238,565\end{array}$} \\
\hline PP\&E & 100 & 232,078 & $J O D$ & 227,599 & $J O D$ & 232,151 & 100 & 227,508 & $J O D$ & 222,958 & $J O D$ & \\
\hline change PP\&E & & & $J O D$ & 4,479 & 100 & 4,552 & 100 & 4,643 & $J O D$ & 4,550 & 100 & 15,607 \\
\hline Depreciation & & & $J O D$ & 63,457 & $10 D$ & 64,726 & 100 & 63,432 & $J O D$ & 62,163 & $1 O D$ & 66,515 \\
\hline \multirow[t]{2}{*}{ capital expenditures } & & & $J O D$ & 58,978 & $J O D$ & 69,278 & 100 & 58,789 & $J O D$ & 57,613 & $J O D$ & 82,122 \\
\hline & & \multicolumn{2}{|l|}{2016} & \multicolumn{2}{|c|}{2017} & \multicolumn{2}{|l|}{2018} & \multicolumn{2}{|l|}{2019} & \multicolumn{2}{|l|}{2020} & 2021 \\
\hline Net working capital & joD & 374,557 & $J O D$ & 352,350 & 100 & 346,311 & 100 & 369,156 & $J O D$ & 409,809 & 100 & 455,930 \\
\hline change in net Working capital & & & $J O D$ & 22,207 & -100 & $6,039-$ & $\mathrm{jOD}$ & 22,846 & $J O D$ & 40,653 & $J O D$ & 46,121 \\
\hline \multicolumn{13}{|l|}{ Free cash flow } \\
\hline & & \multicolumn{2}{|l|}{2017} & \multicolumn{2}{|c|}{2018} & \multicolumn{2}{|l|}{2019} & \multicolumn{2}{|l|}{2020} & \multicolumn{2}{|l|}{2021} & \\
\hline Net income & joD & 87,566 & $J O D$ & 106,745 & 100 & 125,222 & 100 & 144,288 & $J O D$ & 176,290 & & \\
\hline depreciation & JOD & 63,457 & $J O D$ & 64,726 & 100 & 63,432 & $j 00$ & 62,163 & $J O D$ & 66,515 & & \\
\hline Amortization & JOD & 1,021 & $J O D$ & 1,021 & 100 & 1,021 & 100 & 1,021 & $J O D$ & 1,021 & & \\
\hline capital expenditures & JOD & 58,978 & 100 & 69,278 & 100 & 58,789 & JOD & 57,613 & $J O D$ & 82,122 & & \\
\hline change in working capital & joo & 22,207 & $J O D$ & 6,039 & -100 & 22,846 & 100 & 40,653 & $J O D$ & 46,121 & & \\
\hline Free cash flow & joo & 115,274 & $J O D$ & 109,254 & 100 & 108,040 & $J 00$ & 109,207 & $J O D$ & 115,584 & & \\
\hline
\end{tabular}

Appendix 8: WACC

risk free rate
beta
Adjusted beta
market risk premium
camp ( cost of equity)
Cost of debt after tax
Market value equity JOD
market value debt
weight equity
weight debt
WACC


Int. Business Manage., 13 (4): 134-150, 2019

Appendix 9: Valuation

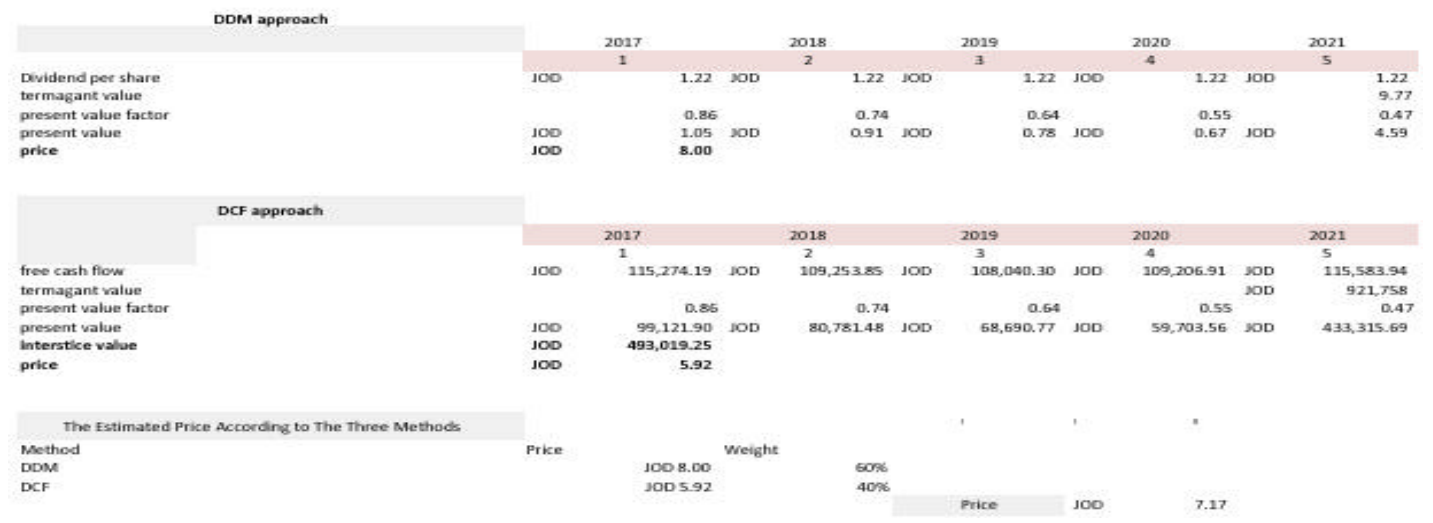

Appendix 10: Beta

\begin{tabular}{|c|c|c|c|c|c|c|c|c|}
\hline Potash price & ASE Index & tash Return & Index Return & Potash AVG Retum & Index AVG Retura & Potash Return - AVG & Index Return - AVG & $H^{*}$ \\
\hline 46.51 & 1957.6 & 0 & 0 & -0.012972496 & 0.001632662 & 0.012972496 & -0.001632662 & $-2.11797 \mathrm{E}-05$ \\
\hline 46.55 & 2045.7 & 0.00086003 & 0.04502017 & -0.012972496 & 0.001632662 & 0.013832526 & 0.043387508 & 0.000600159 \\
\hline 44.2 & 2042.4 & -0.050483351 & -0.001616152 & -0.012972496 & 0.001632662 & -0.037510855 & -0.003248814 & 0.000121866 \\
\hline 45.97 & 2101.4 & 0.040045249 & 0.028857765 & -0.012972496 & 0.001632662 & 0.053017745 & 0.027225103 & 0.001443414 \\
\hline 45 & 1998.1 & -0.021100718 & -0.049127024 & -0.012972496 & 0.001632662 & -0.008128222 & -0.050759686 & 0.000412586 \\
\hline 47.25 & 2017.5 & 0.05 & 0.00967802 & -0.012972496 & 0.001632662 & 0.062972496 & 0.008045358 & 0.000506636 \\
\hline 43.5 & 1980.5 & -0.079365079 & -0.01830663 & -0.012972496 & 0.001632662 & -0.066392583 & -0.019939292 & 0.001323821 \\
\hline 42.49 & 1956.5 & -0.023218391 & -0.012123805 & -0.012972496 & 0.001632662 & -0.010245895 & -0.013756467 & 0.000140947 \\
\hline 36 & 1875.0 & -0.152741822 & -0.041689104 & -0.012972496 & 0.001632662 & -0.139769326 & -0.043321766 & 0.006055054 \\
\hline 23.8 & 1850.6 & -0.338888899 & -0.012994956 & -0.012972496 & 0.001632662 & -0.325916393 & -0.014627618 & 0.00476738 \\
\hline 29.4 & 1969.3 & 0.235294118 & 0.064165548 & -0.012972496 & 0.001632662 & 0.248266614 & 0.062532886 & 0.015524828 \\
\hline 28.85 & 2022.6 & -0.018707483 & 0.027060509 & -0.012972496 & 0.001632662 & -0.005734987 & 0.025427847 & -0.000145828 \\
\hline 28.05 & 2065.8 & -0.027729636 & 0.021359468 & -0.012972496 & 0.001632662 & -0.01475714 & 0.019726806 & -0.000291111 \\
\hline 27.4 & 2207.0 & -0.023172906 & 0.068315448 & -0.012972496 & 0.001632662 & -0.01020041 & 0.066682786 & -0.000680192 \\
\hline 26.26 & 2178.2 & -0.041605839 & -0.013042358 & -0.012972496 & 0.001632662 & -0.028633343 & -0.01467502 & 0.000420195 \\
\hline 26.81 & 2148.9 & 0.020944402 & -0.01342531 & -0.012972496 & 0.001632662 & 0.033916898 & -0.015057972 & -0.00051072 \\
\hline 27.9 & 2124.2 & 0.040656471 & -0.011530754 & -0.012972496 & 0.001632662 & 0.053628967 & -0.013163416 & -0.00070594 \\
\hline 26.6 & 2130.9 & -0.046594982 & 0.003186363 & -0.012972496 & 0.001632662 & -0.033622486 & 0.01553701 & $-5.22393 \mathrm{E}-05$ \\
\hline 25.8 & 2113.0 & -0.030075188 & -0.008393756 & -0.012972496 & 0.001632662 & -0.017102692 & -0.010026418 & 0.000171479 \\
\hline 26.25 & 2136.6 & 0.01744186 & 0.011139562 & -0.012972496 & 0.001632662 & 0.030414356 & 0.0095069 & 0.000289146 \\
\hline 23.6 & 2131.9 & -0.100952381 & -0.002182446 & -0.012972496 & 0.001632662 & -0.087979885 & -0.003815108 & 0.000335653 \\
\hline 22.99 & 2115.0 & -0.025847458 & -0.007941677 & -0.012972496 & 0.001632662 & -0.012874962 & -0.009574339 & 0.000123269 \\
\hline 22.48 & 2106.1 & -0.022183558 & -0.004183724 & -0.012972496 & 0.001632662 & -0.009211062 & -0.005816386 & $5.35751 \mathrm{E}-05$ \\
\hline 20 & 2132.5 & -0.110320285 & 0.012515555 & -0.012972496 & 0.001632662 & -0.097347789 & 0.10882893 & -0.001059426 \\
\hline 19.5 & 2165.5 & -0.025 & 0.015460153 & -0.012972496 & 0.001632662 & -0.012027504 & 0.013827491 & -0.00016631 \\
\hline 18.8 & 2169.6 & -0.035897436 & 0.00191744 & -0.012972496 & 0.001632662 & -0.02292494 & 0.000284778 & $-6.52852 \mathrm{E}-06$ \\
\hline 17.99 & 2195.5 & -0.045212766 & 0.01191466 & -0.012972496 & 0.001632662 & -0.03224027 & 0.010281998 & -0.000331494 \\
\hline 16.01 & 2135.4 & -0.108077994 & -0.027344638 & -0.012972496 & 0.001632662 & -0.095105498 & -0.0289773 & 0.002755901 \\
\hline 15.8 & 2115.5 & -0.013116802 & -0.009318626 & -0.012972496 & 0.001632662 & -0.000144306 & -0.10951288 & $1.58034 E-06$ \\
\hline 20.75 & 2183.6 & 0.313291139 & 0.032165659 & -0.012972496 & 0.001632662 & 0.326263635 & 0.030532997 & 0.009961807 \\
\hline 21.5 & 2115.6 & 0.036144578 & -0.031110818 & -0.012972496 & 0.001632662 & 0.049117074 & -0.03274348 & -0.001608264 \\
\hline 23.45 & 2125.7 & 0.090697674 & 0.004765946 & -0.012972496 & 0.001632662 & 0.10367017 & 0.003133284 & 0.000324828 \\
\hline 23 & 2097.6 & -0.019189765 & -0.013236543 & -0.012972496 & 0.001632662 & -0.006217269 & -0.014869205 & 9.24459E-05 \\
\hline $21.3 z^{2}$ & 2045.2 & -0.073043478 & -0.02496167 & -0.012972496 & 0.001632662 & -0.060070982 & -0.026594332 & 0.001597548 \\
\hline 21.48 & 2034.4 & 0.00750469 & -0.005284781 & -0.012972496 & 0.001632662 & 0.020477186 & -0.006917443 & -0.00014165 \\
\hline 20.6 & 1993.7 & -0.040968343 & -0.020006098 & -0.0129724966 & 0.001632662 & -0.027995847 & -0.02163876 & 0.000605795 \\
\hline & 2136.3 & 0.019417476 & 0.071526704 & -0.012972496 & 0.001632662 & 0.032389972 & 0.069894042 & 0.002263866 \\
\hline & 2147 & 057619048 & 0.004999461 & -0.012972496 & 0.001632662 & -0.044646552 & 0.003366799 & 0.0001503 \\
\hline
\end{tabular}


Int. Business Manage., 13 (4): 134-150, 2019

Appendix 10: Beta

\begin{tabular}{|c|c|c|c|c|c|c|c|c|}
\hline 19. & 2116.2 & -0.02475998 & -0.014325383 & -0.012972496 & 0.001632662 & -0.011787484 & -0.015958045 & 0.000188105 \\
\hline 19 & 2151.9 & -0.015544041 & 0.01684536 & -0.012972496 & 0.001632662 & -0.002571545 & 0.015212698 & $-3.91201 E-05$ \\
\hline 17.24 & 2094.7 & -0.092631579 & -0.026569511 & -0.012972496 & 0.001632662 & -0.079659083 & -0.028202173 & 0.002246559 \\
\hline 17 & 2118.4 & -0.013921114 & 0.011325493 & -0.012972496 & 0.001632662 & -0.000948618 & 0.009692831 & $-9.19479 E-06$ \\
\hline 17.15 & 2091.4 & 0.009823529 & -0.012788118 & -0.012972496 & 0.001632662 & 0.021796025 & -0.01442078 & -0.000314316 \\
\hline 1678 & 2102.1 & -0.023323615 & 0.005154502 & -0.012972496 & 0.001632662 & -0.010351119 & 0.00352184 & $-3.6455 \mathrm{E}-05$ \\
\hline 16 & 2076.8 & -0.044776119 & -0.012035193 & -0.012972496 & 0.001632662 & -0.031803623 & -0.013667855 & 0.000434687 \\
\hline 15.6 & 2120.5 & -0.025 & 0.021007606 & -0.012972496 & 0.001632662 & -0.012027504 & 0.019374944 & -0.000233032 \\
\hline 15.52 & 2107.6 & -0.005128205 & -0.006076546 & -0.012972496 & 0.001632662 & 0.007844291 & -0.007709208 & $-6.04733 \mathrm{E}-05$ \\
\hline 17.5 & 2171.0 & 0.12757732 & 0.030083405 & -0.012972496 & 0.001632662 & 0.140549816 & 0.028450743 & 0.003998747 \\
\hline 19.18 & 2170.3 & 0.096 & -0.00031768 & -0.012972496 & 0.001632662 & 0.108972496 & -0.001950342 & -0.000212534 \\
\hline 17.5 & 2161.5 & -0.087591241 & -0.004062589 & -0.012972496 & 0.001632662 & -0.074618745 & -0.005695251 & 0.000424972 \\
\hline 17.1 & 2212.8 & -0.022857143 & 0.023727317 & -0.012972496 & 0.001632662 & -0.009884647 & 0.022094655 & -0.000218398 \\
\hline 17.76 & 2250.2 & 0.038596491 & 0.016910077 & -0.012972496 & 0.001632662 & 0.051568987 & 0.015277415 & 0.000787841 \\
\hline 19 & 2185.3 & 0.06981982 & -0.028850163 & -0.012972496 & 0.001632662 & 0.082792316 & -0.030482825 & -0.002523744 \\
\hline 18.8 & 2175.2 & -0.005263158 & -0.004614365 & -0.012972496 & 0.001632662 & 0.007709338 & -0.006247027 & $-4.81604 E-05$ \\
\hline 18.e & 2167.4 & -0.015873016 & -0.003574634 & -0.012972496 & 0.001632662 & -0.00290052 & -0.005207296 & $1.51039 \mathrm{E}-0 \mathrm{5}$ \\
\hline 18.78 & 2139.8 & 0.010215054 & -0.012726299 & -0.012972496 & 0.001632662 & 0.02318755 & -0.014358961 & -0.000332949 \\
\hline 18.35 & 2157.3 & -0.023416711 & 0.00815156 & -0.012972496 & 0.001632662 & -0.010444215 & 0.006518898 & $-6.80848 \mathrm{BE}-05$ \\
\hline 18 & 2121.5 & -0.019073569 & -0.016566084 & -0.012972496 & 0.001632662 & -0.006101073 & -0.018198746 & 0.000111032 \\
\hline 7 & 2093.2 & -0.0555555556 & -0.013355243 & -0.012972496 & 0.001632662 & -0.04258306 & -0.014987905 & 0.000638231 \\
\hline 17 & 2122.5 & 0 & 0.013990489 & -0.012972496 & 0.001632662 & 0.012972496 & 0.012357827 & 0.000160312 \\
\hline 16.85 & 2126.8 & -0.008823529 & 0.002030794 & -0.012972496 & 0.001632662 & 0.004148967 & 0.000398132 & $1.65184 \mathrm{E}-\mathrm{C}$ \\
\hline
\end{tabular}

$0.000802186 \quad 0.000562746$

$\begin{array}{lr}\text { Beta } & 1.425495508 \\ \text { Adjusted Beta } & 1.28507529\end{array}$

Appendix 11: Investment summary

\begin{abstract}
Bask of our alks growth rate: MT to be $350000 \mathrm{MT}$, this project will roquire a total investment of 200 milion dolars.

2. Demand for agricultual product wil increase for the following reason.

- Over the ten year outlook period, demand is projected to grow more slowily.

- Future growth in crop producton will be attained mostly by ncresing velds, and growth in meat and dairy production.

- Agrkultural trade is expoted to grow more sbouly, but remain less sensitive to weak economic conditions than other sectors.

- Real prices are equected to remain flat $\alpha$ dedine for most commod ties.
\end{abstract}

1. Recenty in 2018Kemapco signed an agreement with Yare hternatonal, a major fertlizer producing company. This agreement will resalt in the construction of a new manufacturing plant which will increase the capacity by 175000

3. Cilmate change. for the decade, a waming of 0.1 degrees is eqpected globally, an increse in temperature is better for pant growth, thus an increas in fertlaer demand is most ikely to occur.

"'" all forecasted accounts in the income statement and balance sheet were based on rational team estimates. 
Appendix 12: Porter's five forces model

Appendix 12: Porter's Five Forces Mode]

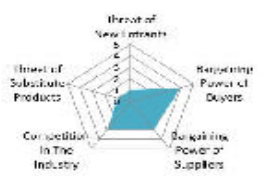

Threat of New Entrans,

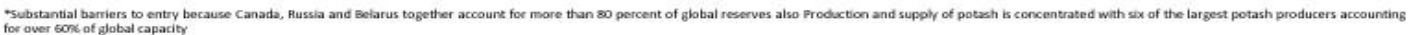

- Only companies with High characterístic (high capscity, bow production cost) can face globat competition

- Large economies ot scalie to profit |Small players will not be successfult.

competition in the industry.

- Large companies dominate the industry fisgh concentration, low halance!

- Potzash industry operates in giobal market (internatonal foctor)

- Lower of Evisting competitors (merger Potash corp and Agriam to competition for increasing market share)

- Matural resources are differentiy bocated fpotash reservere is high in some countriest

Borgaining Power of Suppllers,

- Bxist of raw material |avaliable for producer)

PPotash signvificance is increasing with time

Bargaining Power of Bupers,

* Lacks a diversified or balance market kconcentration threat;

- Low switching cost (joroduct $\mathrm{k}$ undifferentiated)

- Long term contracts are imolved

The risk of beyer's backward integration is insignificant

Threat of Substitute Products

"No superiar substitute evista

- The inervention of the human factor| Genetically modfied crops can reduce demand for potash

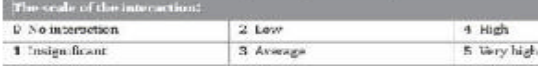

Appendix 13: Stock price and dividend

\begin{tabular}{|c|c|c|c|c|}
\hline & 20012 & 2013 & 2014 & 2015 \\
\hline $\begin{array}{l}\text { Dividend paic } \\
\text { Closings peice }\end{array}$ & $\frac{208293100}{46.15100}$ & $\frac{124973100}{2805100}$ & $\frac{99081100}{195100}$ & $\frac{99931.000}{21100}$ \\
\hline \multicolumn{5}{|c|}{ Dividend paid in thousands Jon } \\
\hline \multicolumn{5}{|c|}{ This proves our justification to give DDMe method a higher weight in valuation } \\
\hline \multicolumn{5}{|c|}{$\begin{array}{l}\text { Appendix } 14 \\
\text { Key facts }\end{array}$} \\
\hline \multicolumn{3}{|c|}{ Name } & \multicolumn{2}{|c|}{ Arab Potash Company (APC) } \\
\hline \multicolumn{3}{|c|}{ Founded } & \multicolumn{2}{|c|}{1956} \\
\hline \multicolumn{3}{|c|}{ Logo } & \multicolumn{2}{|c|}{ 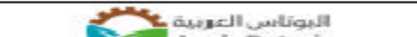 } \\
\hline \multicolumn{3}{|c|}{ Industries served } & \multicolumn{2}{|c|}{$\begin{array}{l}\text { Mining and Extraction } \\
\text { Industries }\end{array}$} \\
\hline & \multicolumn{2}{|c|}{ Geographic areas served } & \multicolumn{2}{|c|}{$\begin{array}{l}\text { Worldwide (more than } 140 \\
\text { countries) }\end{array}$} \\
\hline & \multicolumn{2}{|l|}{ Headquarters } & \multicolumn{2}{|c|}{ Amman - Jordan } \\
\hline & \multicolumn{2}{|l|}{ Current CEO } & \multicolumn{2}{|c|}{ Brent Edward Heimann } \\
\hline & \multicolumn{2}{|l|}{ Revenue (USD) } & \multicolumn{2}{|c|}{$\begin{array}{c}595.910 \text { million }(2017) \\
\text { increase over } 520.413 \text { million } \\
(2016)\end{array}$} \\
\hline & \multicolumn{2}{|l|}{ Profit (USD) } & \multicolumn{2}{|c|}{$\begin{array}{c}126.485 \text { million }(2017) 44.3 \% \\
\text { increase over } 87.630 \text { million } \\
(2016)\end{array}$} \\
\hline & \multicolumn{2}{|l|}{ Employees } & \multicolumn{2}{|c|}{$1,811(2017)$} \\
\hline
\end{tabular}

\section{REFERENCES}

Anonymous, 2013. Arab Potash Company (APC) annual report. APC Company, Amman, Jordan. http://www.arabpotash.com/EchoBusV3.0/System Assets/PDFAR/2013 annual english.pdf

Anonymous, 2014. Arab Potash Company (APC) annual report. APC Company, Amman, Jordan. http://www.arabpotash.com/EchoBusV3.0/System Assets/PDFAR/2014_annual_english.pdf
Anonymous, 2015. Arab Potash Company (APC) annual report. APC Company, Amman, Jordan. http : / / www . arabpotash . com / Echo Bus V3.0/SystemAssets/images/Annual/2015_annual_e nglish.pdf

Anonymous, 2016. Arab Potash Company (APC) annual report. APC Company, Amman, Jordan. http://www.arabpotash.com/EchoBus V3.0/SystemAssets/PDFAR/2016_annual_english. pdf 
Anonymous, 2017. Arab Potash Company (APC) annual report. APC Company, Amman, Jordan. http://www arabpotash. com/EchoBusV3.0/System Assets/PDFAR/Annual\%20report\%202017\%20Eng lish.pdf

Anonymous, 2018. Arab Potash Company (APC) annual report. APC Company, Amman, Jordan.http://www.arabpotash.com/echobusv 3. 0/systemassets/9f495bca-2b6e-469f-8158-e9e305f1 2 d31.pdf

Dyson, R.G., 2004. Strategic development and SWOT analysis at the University of Warwick. Eur. J. Operat. Res., 152: 631-640.
Houben, G., K. Lenie and K. Vanhoof, 1999. A knowledge-based SWOT-analysis system as an instrument for strategic planning in small and medium sized enterprises. Decis. Support Syst., 26: 125-135.

Kangas, J., M. Kurtila, M. Kajanus and A. Kangas, 2003. $\mathrm{A}$, evaluating the management strategies of a forestland estate-the S-O-S approach. J. Environ. Manag., 69: 349-358.

Le, A., 2017. Equity valuation using discounted cash flow method-A case study: Viking line Ltd. BA Thesis, Arcada University of Applied Sciences, Helsinki, Finland.

Yuksel, I. and M. Dagdeviren, 2007. Using the Analytic Network Process (ANP) in a SWOT analysis. A case study for a textile firm. J. Inform. Sci., 177: 3364-3382. 